\title{
Invited review: The importance of colostrum in the newborn dairy calf
}

\author{
A. J. Lopez and A. J. Heinrichs* \\ Department of Animal Science, The Pennsylvania State University, University Park 16802
}

\begin{abstract}
It is critical that bovine maternal colostrum is fed to newborn calves during their first hours of life. Colostrum is the secretion a cow produces after mammary involution that is rich in various nutrients. In addition to the nutritive value for newborn calves, immunoglobulins are of interest due to their role in developing the naïve immune system of calves at birth. The process by which a calf acquires immunity via absorption of immunoglobulins is defined as passive immunity. When calves consume an adequate amount of immunoglobulins, they are classified as having successful passive immunity (SPI). In contrast, if they are deprived of adequate colostrum, they are considered to have had a failure of transfer of passive immunity (FPI). Transfer of passive immunity is assessed by measuring serum IgG concentrations at 24 to $48 \mathrm{~h}$ of age. The major factors that influence whether a calf has SPI or FPI are colostrum IgG concentration, quantity fed, and age of calf at colostrum feeding. Monitoring apparent efficiency of immunoglobulin absorption in calves is often recommended to evaluate overall colostrum management practices. Serum IgG analyses can be determined with direct (radial immunodiffusion) or indirect (refractometry) methods and used to assess SPI or FPI prevalence.
\end{abstract}

Key words: colostrum, immunoglobulin, passive immunity, radial immunodiffusion, refractometry

\section{INTRODUCTION}

Research into passive transfer of immunity started between 1892 and 1893 with work by Paul Ehrlich, who studied how maternal antibodies were transferred to newborn animals. Ehrlich was the first to differentiate between active and passive immunity (Silverstein, 1996). At birth, calves can absorb immunoglobulins from maternal colostrum through their small intestine, but the closure of intestinal permeability to those proteins accelerates as calf age exceeds $12 \mathrm{~h}$ after birth, and perme-

Received December 31, 2020.

Accepted October 3, 2021.

*Corresponding author: ajh@psu.edu ability ceases completely at $24 \mathrm{~h}$ postpartum (Stott et al., 1979b). This was corroborated by Bush and Staley (1980), who stated that cessation of IgG absorption from epithelial cells to the bloodstream increases after $12 \mathrm{~h}$ of age with final closure at $24 \mathrm{~h}$. Gut closure is defined when the gut is unable to absorb macromolecules and transfer them into blood circulation (Leece and Morgan, 1962). Early research stated that diet did not affect gut closure (Patt, 1977), but Stott et al. (1979a) discussed how feeding colostrum hastened cessation and that colostrum-deprived calves experienced delayed gut closure. Moreover, Stott et al. (1979b) explained that colostrum feeding stimulates pinocytosis, which is the means of transport of immunoglobulins. Macromolecule absorption begins to shut down after that, although transport into the bloodstream is still active. Additionally, Stott et al. (1979b) reported that gut closure in calves is a mechanism for minimizing macromolecule absorption after colostrum ingestion. The exact mechanism controlling this permeability is not clear (Weaver et al., 2000); however, this gut closure is believed to be the result of the depletion of pinocytotic activity or the replacement of enterocytes with mature epithelial cells (Broughton and Lecce, 1970; Smeaton and SimpsonMorgan, 1985). Furthermore, it has been shown that absorption efficiency decreases as the time between birth and first colostrum feeding increases, making the timing of colostrum offering to a newborn calf crucial (Bush and Staley, 1980). More recently, Fischer et al. (2018) reported that a delay in colostrum feeding past $6 \mathrm{~h}$ after birth decreased transfer of IgG in comparison with calves fed right after birth, corroborating that calves should be fed immediately after birth. However, data show that calves are able to absorb IgG when deprived from colostrum feeding up to $48 \mathrm{~h}$. Specifically, when colostrum is first fed at $6,12,24,36$, and $48 \mathrm{~h}$ after birth, $65.8,46.9,11.5,6.7$, and $6.0 \%$ of total ingested IgG, respectively, appeared in plasma (Matte et al., 1982). Recently, Osaka et al. (2014) reported that calves fed within 1,1 to 6,6 to 12 , and 12 to $18 \mathrm{~h}$ after birth have apparent efficiency of absorption (AEA) values of 30.5, 27.4, 23.7, and 15.8\%, respectively. Another factor that has been demonstrated to influence how the small intestine matures or closes is IGF-1. Although its role in gut maturation has not been 
clearly characterized (Pyo et al., 2020), it is known that IGF-1 is present in large quantities in maternal colostrum and is one of the 2 most abundant growth factors present in colostrum along with IGF-2 at levels of 50 to $2,000 \mu \mathrm{g} / \mathrm{L}$ (Pakkanen and Aalto, 1997; Marnila and Korhonen, 2002). Pyo et al. (2020) hypothesized that colostrum intake might influence gut development by elevating serum IGF-1 concentrations. However, Pyo et al. (2020) concluded that feeding colostrum for $3 \mathrm{~d}$ minimally increased serum IGF-1. In addition, Pyo et al. (2020) concluded that the increase in IGF-1 concentrations was more likely related to the increased amount of energy and nutrient consumption from colostrum, rather than by gut development. In addition to timing, the major factors that affect colostral immunoglobulin absorption are immunoglobulin concentration in colostrum, total volume of colostrum offered at first feeding (Stott and Fellah, 1983), and thus the total grams of immunoglobulins consumed, and bacterial levels in colostrum (Gelsinger et al., 2015). Although it is common that research studies emphasize IgG concentration as one of the major elements in colostrum quality (Godden et al., 2009a; Elsohaby et al., 2017; Heinrichs et al., 2020), bacterial contamination should be included as its presence in colostrum has potential negative effects on newborn calves (Gelsinger et al., 2015). Heat treatment of colostrum can enhance IgG absorption and increase plasma IgG concentration by $18.4 \%$ (Gelsinger et al., 2014) while being an excellent method to reduce bacteria populations in colostrum (Heinrichs et al., 2020). Nevertheless, it should be considered that heat treatment be rigorously controlled, as its duration can affect high and low abundance proteins in bovine colostrum (Tacoma et al., 2017). Tacoma et al. (2017) mentioned that changes in the proteome could affect calf development when the bioactive components are reduced. However, no data has been reported that show negative calf effects from feeding heat-treated colostrum. It has been reported that heating colostrum at $60^{\circ} \mathrm{C}$ for 30 or 60 min minimally decreases or does not affect $\operatorname{IgG}$ concentration, reduces bacterial count, and does not affect viscosity (Johnson et al., 2007; Elizondo-Salazar et al., 2010).

When calves do not receive sufficient immunoglobulin, they are classified as having failure of passive immunity (FPI; Lombard et al., 2020), which places them at greater risk for illness in the first weeks of life (Renaud et al., 2018; Todd et al., 2018). Calves are considered to have FPI when their serum IgG concentration is $<10$ $\mathrm{mg} / \mathrm{mL}$ at $24 \mathrm{~h}$ of age (Besser et al., 1991; FurmanFratczak et al., 2011; Shivley et al., 2018). In contrast, they are considered as having successful passive immunity (SPI; Lombard et al., 2020) when their serum
IgG concentration is $>10 \mathrm{mg} / \mathrm{mL}$ at $24 \mathrm{~h}$ (Weaver et al., 2000; Quigley, 2004; Godden, 2008). Recent studies have discussed that higher serum IgG thresholds to determine FPI should be evaluated. For example, Urie et al. (2018b) stated calves with serum IgG levels $>15$ $\mathrm{mg} / \mathrm{mL}$ have reduced morbidity and mortality rates in comparison with the standard cutoff point of $10 \mathrm{mg} /$ $\mathrm{mL}$ IgG that is currently used. Similarly, FurmanFratczak et al. (2011) concluded that calves with serum IgG levels $>15 \mathrm{mg} / \mathrm{mL}$ did not develop respiratory infections. Reports evaluating beef calves have recommended that serum IgG values of $>24$ and $>27 \mathrm{mg} /$ $\mathrm{mL}$ decrease morbidity rates and result in increased BW gains (Dewell et al., 2006; Waldner and Rosengren, 2009). Lombard et al. (2020) recently proposed that the term transfer of passive immunity (TPI) should replace the more common term, passive transfer, because the immunity transferred is passive but not the absorption of immunoglobulins. Additionally, Lombard et al. (2020) introduced a new TPI standard that includes the following 4 defined categories of serum IgG: excellent, good, fair, and poor with serum IgG levels of $\geq 25.0,18.0$ to $24.9,10.0$ to 17.9 , and $<10.0 \mathrm{mg} / \mathrm{mL}$, respectively. They suggested that on a herd level, $>40$, 30,20 , and $10 \%$ of calves should be in the excellent, good, fair, and poor TPI categories, respectively.

Colostrum feeding is an important component of calf management programs (Godden, 2008). However, when fresh maternal colostrum is not available at birth or is not of high quality, farmers have the alternative to use colostrum replacers (CR) or colostrum supplements (Lopez et al., 2020a). Colostrum products are considered as replacement feeding when they provide $>100$ g of IgG per dose (McGuirk and Collins, 2004; Foster et al., 2006). Colostrum products containing $<100 \mathrm{~g}$ of IgG per dose are considered supplements and are not a complete replacement of a maternal colostrum feeding (Quigley et al., 2002). Colostrum replacers should not replace a high-quality maternal colostrum feeding but have been determined to provide a valid alternative for immunoglobulins with no negative effect on calf performance (Lago et al., 2018). In contrast, colostrum supplements do not contain sufficient IgG to replace maternal colostrum and are formulated to be given in conjunction with colostrum to enhance $\operatorname{IgG}$ concentration (Quigley, 2004; Jones and Heinrichs, 2006).

\section{IMPORTANCE OF COLOSTRUM}

\section{Nutrition}

Newborn calves require high-quality colostrum if they are to absorb enough immunoglobulins to achieve 
successful TPI (Morin et al., 2021a,b). Colostrum is the first secretion a cow produces after mammary involution. Bovine colostrum is produced and accumulated during late pregnancy in a process defined as colostrogenesis (Baumrucker and Bruckmaier, 2014). It has been reported that colostrum formation starts 3 to 4 wk before calving and ceases abruptly before parturition (Brandon et al., 1971). Nevertheless, the exact time when colostrum forms in individual cows is unknown, which may partially explain the great variation observed in colostrum quality (Kehoe et al., 2007; Baumrucker et al., 2010). Colostrum is mainly composed of immunoglobulins, which provide immunity to a calf for the first weeks of life. In addition, it is the first nutrient supply for the calf at birth and contributes to intestinal protection against pathogens (Foley and Otterby, 1978; Davis and Drackley, 1998; Calloway et al., 2002). Colostrum is a concentrated source of nutrients with 1.85 times the DM, 4.52 times more protein, 1.68 times more fat, and greater concentrations of minerals and vitamins than whole milk (Foley and Otterby, 1978). In addition to lactose, bovine colostrum also contains small amounts of some other sugars (i.e., glucose, fructose, glucosamine, and galactosamine) and oligosaccharides (Gopal and Gill, 2000). Colostrum is an energy source for calves during the first hours of life because they are born with limited energy reserves (Morrill et al., 2012). Only 3\% of the newborn calf's BW is lipid, and it is primarily structural, which limits its availability for metabolism by the calf (Morrill et al., 2012). As a result, calves depend on the lipids and lactose present in maternal colostrum as an energy source during the first hours of life (Morrill et al., 2012). Colostrum also contains carbohydrates, various other proteins, growth factors, enzymes, enzyme inhibitors, nucleotides, nucleosides, cytokines, and fats. (McGrath et al., 2016). In addition, there are essential vitamins and minerals present in bovine colostrum including calcium, magnesium, iron, manganese, zinc, vitamin $\mathrm{E}$, vitamin A, riboflavin, carotene, vitamin B12, folic acid, choline, and selenium (Foley and Otterby, 1978; Hammon et al., 2000). Fat-soluble vitamins have been considered an important component of colostrum; however, the water-soluble vitamins have not been researched to the same extent (Kehoe et al., 2007). The 2 major compounds of vitamin E include tocopherols and tocotrienols (Morrissey and Hill, 2009). However, although tocopherols can cross the placenta and be stored by the fetus, newborn calves have low tocopherol levels at birth and require colostrum ingestion to compensate (Zanker et al., 2000). It is known that the supplementation of vitamins, such as fat-soluble vitamins, during the dam's dry period increases their concentrations in colostrum (Weiss et al., 1990). Specifically, Weiss et al. (1990) found that supplementing vitamin E for approximately $60 \mathrm{~d}$ increased $\alpha$-tocopherol levels in colostrum. Parrish et al. (1949) mentioned that tocopherol supplementation to the cow increased vitamin A levels in colostrum. Colostrum also contains vitamin D, which is synthesized by cows when exposed to UV radiation (Bulgari et al., 2013). Fischer-Tlustos et al. (2020) reported that first-milking colostrum and transition milk have elevated concentrations of some oligosaccharides including 3 '-sialyllactose and 6'-sialyllactose compared with milk, and they stated that these have beneficial effects for the calf such as protection of intestinal mucosa by adhering with bacteria (Martín et al., 2002). Overall, maternal colostrum provides both nutrients and nonnutrient factors that help the immune system become active, mature the intestine, and promote organ development (Hammon et al., 2020).

The components of colostrum can vary depending on factors such as breed, parity, pre-partum nutrition, dry period length, diet, age of animal, and previous disease exposure (Parrish et al., 1948; Tsioulpas et al., 2007; Mann et al., 2016). In addition, environmental factors and mammary gland interaction with certain pathogens can increase immune factor concentrations in milk (Barrington et al., 1997; Stelwagen et al., 2009). A nationwide evaluation of colostrum quality in US dairy farms done by Morrill et al. (2012) supported Parrish et al. (1948) and Tsioulpas et al. (2007) regarding the increase of IgG concentration as the cow's parity increases $(42.4,68.6$, and $95.9 \mathrm{mg} / \mathrm{mL}$ in first, second, and third lactation, respectively). However, this evaluation concluded that $60 \%$ of maternal colostrum on US dairy farms was inadequate considering IgG concentration and bacteria total plate counts (Morrill et al., 2012).

Results from Kehoe et al. (2007), Swan et al. (2007), Baumrucker et al. (2010), and Morrill et al. (2012) have reported a wide variation of colostral mean IgG concentrations and other components. Baumrucker and Bruckmaier (2014) reviewed and emphasized the extreme variation of IgG concentrations in colostrum between cows. Components such as fat, protein, lactose, and total solids have also been reported with considerable ranges (Kehoe et al., 2007; Morrill., et al., 2012). Fat can vary from 1 to $26.5 \%$, lactose from 1.2 to $5.2 \%$, protein from 2.6 to $22.6 \%$, and total solids from 1.7 to $43.3 \%$ (Kehoe et al., 2007; Morrill., et al., 2012). A more recent review about colostrum composition by McGrath et al. (2016) included components such as growth factors (i.e., epidermal growth factor, IGF-1, and IGF-2), cytokines, minerals, and $\mathrm{pH}$, where they summarized how these components are variable in colostrum in comparison to mature milk. 


\section{Immunity}

At birth, calves have an immature immune system because the dam's placental structure prevents maternal serum IgG transfer to the calf (Davis and Drackley, 1998). The bovine has a syndesmochorial placenta with 3 maternal and 3 fetal layers that act as barriers and interfere with immunoglobulin transfer (Blum and Baumrucker, 2008; Peter, 2013). As a result, calves are born deficient of antibodies and depend on ingestion of colostrum to acquire immunoglobulins (Davis and Drackley, 1998; Calloway et al., 2002). Adequate colostrum feeding will determine if a newborn experiences SPI or FPI. Failure of passive immunity is related to increased calf mortality and morbidity rates (FurmanFratczak et al., 2011; Urie et al., 2018b). Previous reports show US mortality and morbidity rates of 7.8 and $38.5 \%$ (USDA, 2010), which are higher than the recommended guidelines of 5 and $25 \%$ for mortality and morbidity (Dairy Calf and Heifer Association, 2010). Furthermore, Lora et al. (2018) reported that low FPI levels influence the occurrence of enteric diseases. Lora et al. (2018) demonstrated a higher risk of incidence for rotavirus and Cryptosporidium spp. infections, as well as overall diarrhea incidence in calves with FPI. Additionally, it has been shown that adequate colostrum feeding could have a positive long-term effect on the animal, as immunoglobulins ingested from colostrum could have an effect on production and future growth (DeNise et al., 1989). A second colostrum meal 5 to 6 $\mathrm{h}$ postnatal was shown to decrease morbidity rates and improve ADG preweaning (Abuelo et al., 2021). However, Cuttance et al. (2019) reported that FPI did not have an effect on productivity including milk production, growth, reproduction, and lactation performance.

To ensure high IgG concentrations, colostrum must be collected for the first milking immediately following parturition because colostrum quality decreases in subsequent milkings (Stott et al., 1981). It has been shown that IgG decreases in the harvested colostrum when the time interval between calving and colostrum harvest increases (Morin et al., 2010). Specifically, colostrum has higher IgG concentrations when collected within 2 $\mathrm{h}$ after parturition, as its colostral IgG concentration is significantly reduced when collected at 6,10 , and $14 \mathrm{~h}$ after calving (Moore et al., 2005). Early reports stated that 300 to $400 \mathrm{~g}$ of immunoglobulins were required to completely protect newborns against pathogens (Roy, 1980). However, a current recommendation is that 150 to $200 \mathrm{~g}$ of IgG need to be fed at birth for calves to achieve SPI (Chigerwe et al., 2008), yet Godden et al. (2019) suggests feeding total masses above $300 \mathrm{~g}$. Even if a calf achieves SPI through colostrum ingestion, it is imperative to note that the immunity of the calf will not only depend on achieving SPI, but a balance between its immune status and pathogen exposure in its environment, including management and nutritional practices (Swan et al., 2007; Lombard et al., 2020).

\section{IMMUNOGLOBULINS AND OTHER COMPONENTS IN COLOSTRUM}

Transfer of immunoglobulins from the cow's bloodstream to colostrum occurs via an intracellular transport mechanism. There are epithelial receptors that facilitate the transfer of IgG from the blood to the mammary gland (Larson et al., 1980). In general, immunoglobulins are the principal immune components present in bovine colostrum (Stelwagen et al., 2009). The predominant immunoglobulin in colostrum, $\operatorname{IgG}_{1}$, is captured from extracellular fluid and transported to luminal secretions (Larson et al., 1980). The overall transport process of immunoglobulins takes place beginning at $5 \mathrm{wk}$ before parturition and reaches its peak 1 to $3 \mathrm{~d}$ before parturition (Sasaki et al., 1976). Bush et al. (1971) and Oyeniyi and Hunter (1978) reported that IgG concentrations in colostrum decrease with successive milkings postpartum, making the first milking after parturition the highest in IgG content. The decrease in IgG content has been shown by Morin et al. (2010) to be at a rate of $3.7 \%$ for each subsequent hour of colostrum harvest after parturition. Nevertheless, because IgG can still be found in later postpartum milkings (Stott et al., 1981), second- and third-milking colostrum can still be beneficial for calves when it is available. For example, Lopez et al. (2020a) reported no FPI in calves fed second- and third-milking colostrum supplemented with $40 \mathrm{~g}$ of CR as a first feeding. Bovine colostrum typically contains a high concentration of immunoglobulins, specifically IgG rather than other types of immunoglobulins. The IgG class is the major immunoglobulin class that is transferred via colostrum, specifically the $\operatorname{IgG}_{1}$ subclass as mentioned before. The ratio of $\mathrm{IgG}_{1}$ to $\mathrm{IgG}_{2}$ in colostrum is around $7: 1$, and colostrum also contains $\operatorname{IgA}$ and IgM in smaller amounts (Butler et al., 1974). In addition, bovine colostrum contains viable leukocytes (i.e., neutrophils and macrophages) that contribute to the immune components portion of the milk secretions. Bovine IgG concentration ranges from 50 to $150 \mathrm{mg} /$ $\mathrm{mL}$, of which approximately 85 to $95 \%$ is $\mathrm{IgG}, 7 \%$ is $\operatorname{IgM}$, and 5\% is IgA (Butler, 1969; Sasaki et al., 1976; Larson et al., 1980). This range was also reported in specific studies such as Morin et al. (2010) where IgG concentrations ranged from $<10$ to $120 \mathrm{~g} / \mathrm{L}$, and total masses produced ranged from 11 to $681 \mathrm{~g}$. However, it must be appreciated that these percentages can vary greatly among cows. A study conducted by Newby et al. (1982) reported concentrations of $\operatorname{IgG}, \operatorname{Ig} A$, and $\operatorname{IgM}$ 
of $75,4.4$, and $4.9 \mathrm{mg} / \mathrm{mL}$, respectively. The mammary gland regulates the different immunoglobulin class concentrations in colostrum, although the mammary epithelium is generally not involved in their synthesis (Stelwagen et al., 2009). These immunoglobulins appear or can enter colostrum via a paracellular route from intracellular tight junctions (Lacy-Hulbert et al., 1999), but the majority enter through a selective receptor-mediated intracellular route (Stelwagen et al., 2009). However, the mammary gland regulates the immunoglobulin concentrations present in colostrum and also contributes to immunoglobulin appearance by in situ production of its intramammary plasma cells (Stelwagen et al., 2009). The source of different immunoglobulins could be blood-derived or synthesized by intramammary plasma cells (Stelwagen et al., 2009). Overall, the main function of all these types of immunoglobulins is to detect the presence of pathogens present in the calf and eventually protect the animal against them. In general, immunoglobulins are monomeric glycoproteins with high molecular weight and composed of 4-chain molecules, with 2 light (short) and 2 heavy (long) polypeptide chains attached by disulfide bonds (Butler, 1969; Larson, 1992). The IgG class is the major immunoglobulin transferred via colostrum (85-90\%). However, the $\operatorname{IgG}_{1}$ represents 80 to $90 \%$ of total IgG (Butler et al., 1974; Sasaki et al., 1976, Larson et al., 1980). Immunoglobulin G is involved in various activities such as bacterial opsonization and binding to pathogens to inactivate them (Lilius and Marnila, 2001). Immunoglobulin $G_{1}$ is the primary protein involved in the TPI (Butler, 1969; Butler et al., 1974). The role of IgM is to identify and destroy bacteria present in the calf's bloodstream; it functions as a mechanism to fight septicemia and is the principal agglutinating antibody. In addition, IgM has been identified to be the first immunoglobulin to appear in the B lymphocytes (Klein, 1982) and to play a role against mastitis when present in milk (Frenyo et al., 1987). The role of $\operatorname{Ig} \mathrm{A}$ is to prevent the attachment of pathogens and entrance into the intestine by protecting the mucosal membranes (Butler, 1969, 1983; Larson et al., 1980; Blättler et al., 2001; Răducan et al., 2013). Immunoglobulin $\mathrm{E}$ is also found in colostrum, though it is only known for its contribution to skin-sensitizing activity (Butler, 1983). In general, some reports mention that calves start producing their own antibodies, or endogenous production, at approximately $3 \mathrm{wk}$ of age (Devery et al., 1979; Kertz et al., 2017). When determined by clearance of ${ }^{125} \mathrm{I}$-labeled $\mathrm{IgG}_{1}$, passively acquired IgG has an estimated half-life of 11.5 to 17.9 d (Besser, 1993; Besser et al., 1988; Sasaki et al., 1977). In addition, Murphy et al. (2014) reported that the half-life of $\operatorname{IgG}$ derived from maternal colostrum was longer than from CR. They reported that IgG from colostrum had a half-life of $28.5 \mathrm{~d}$ and IgG from CR had a half-life of 19.1 d. Nevertheless, Quigley et al. (2017) reported a higher half-life of $23.9 \mathrm{~d}$ for calves fed a CR that was followed by an increase until wk 8 . It has to be considered that Quigley et al. (2017) fed a high dose of total IgG, $450 \mathrm{~g}$, which may have contributed to this higher half-life. This change of IgG level is due to a normal catabolism the molecules experience (Matte et al., 1982). Macdougall and Mulligan (1969) mentioned that this catabolism rate is about $6 \%$ per day for the first $14 \mathrm{~d}$ of life of a newborn calf. Lopez et al. (2020b) fed either colostrum, CR, or a mixture and showed a linear decrease in IgG levels from initial levels at $24 \mathrm{~h}$ to nadir was $0.44 \mathrm{mg} / \mathrm{mL}$ per day for all treatments. Moreover, Quigley et al. (2017) discussed that the increase of IgG they observed from 4 wk until 8 wk could be associated with a higher IgG de novo synthesis rather than the decay of $\operatorname{IgG}$ derived from maternal concentrations. However, others report that endogenous production depends on IgG consumption. Husband and Lascelles (1975) and Pauletti et al. (2003) have discussed that calves that are not fed colostrum or any source of immunoglobulins experience earlier endogenous antibody production than colostrum-fed calves.

Hallberg et al. (1995) and Andrew (2001) described that colostrum has a higher SCC than regular milk. This increase in SCC is not due to mastitis infection or disease but a result of a physiological feature described as the passage of cells through gaps in the junctions of mammary epithelial cells (Nguyen and Neville, 1998). A study conducted by Ontsouka et al. (2003) demonstrated this SCC difference between colostrum and mature milk. The results reported a mean SCC for colostrum at $\mathrm{d} 2$ of 1,479,000 $\pm 585,000$ cells $/ \mathrm{mL}$ compared with a mean SCC of mature milk (wk 4) of $41,000 \pm 15,000$ cells $/ \mathrm{mL}$. Bovine colostrum can also be a source of pathogens to a newborn calf, such as Escherichia coli, Salmonella spp., Mycoplasma spp., and Mycobacterium avium ssp. paratuberculosis (Houser et al., 2008). These pathogens originate from cow mammary gland infections, improper colostrum storage or handling, and incorrect colostrum harvest (Streeter et al., 1995; Stewart et al., 2005). Colostrum is considered to be of good quality when its IgG concentration is $>50 \mathrm{mg} / \mathrm{mL}$, the bacterial count is $<100,000 \mathrm{cfu} / \mathrm{mL}$, and coliform counts are $<10,000 \mathrm{cfu} / \mathrm{mL}$ (McGuirk and Collins, 2004; Chigerwe et al., 2008).

Another component that has been of interest is trypsin inhibitor concentrations in bovine colostrum due to its possible contribution to inhibit proteolytic degradation of some components (Quigley et al., 2005a). Trypsin inhibitor appears to preserve the activity and benefits the absorption of colostrum components 
(Hernández-Castellano et al., 2014). However, it has to be considered that although heat treatment in colostrum might be beneficial (Gelsinger et al., 2015; Saldana et al., 2019), it also reduces trypsin inhibitor concentrations (Mann et al., 2020). Trypsin inhibitor concentrations in colostrum after parturition are high in comparison to mature milk and decrease approximately one-hundredth by 2 wk after parturition (Sandholm and Honkanen-Buzalski, 1979). Quigley et al. (1995a) reported trypsin inhibitor concentrations in maternal colostrum of $56 \mathrm{mg}$, which is reported as milligrams of trypsin inhibited per deciliter of colostrum. They stated that the presence of trypsin inhibitors was correlated with total immunoglobulins $(\mathrm{r}=0.54)$, fat, total $\mathrm{N}(\mathrm{r}=0.70)$, protein $\mathrm{N}(\mathrm{r}=0.70)$, noncasein $\mathrm{N}$ $(\mathrm{r}=0.64)$, and TS $(\mathrm{r}=0.66)$ in colostrum. Quigley et al. (1995a) concluded that colostrum with higher immunoglobulin content has a higher trypsin inhibitor content, and vice versa, low-quality colostrum has less trypsin inhibitor content, which could affect TPI. Quigley et al. (1995b) found that the addition $1 \mathrm{~g}$ of soybean trypsin inhibitor to $1 \mathrm{~L}$ of colostrum fed to newborn Jersey calves increased serum IgG concentrations from 27.9 to $34.4 \mathrm{mg} / \mathrm{mL}$. In addition to trypsin inhibitor, other components of interest are lactoferrin and transferrin; which are iron-binding proteins (Jenness, 1982). The concentrations of transferrin and lactoferrin have been found to be higher in first-milking colostrum (1.07 and $0.83 \mathrm{mg} / \mathrm{mL}$, respectively) in comparison to further milkings, where concentrations are almost negligible around 3 wk after parturition (0.02 and 0.09 $\mathrm{mg} / \mathrm{mL}$, respectively; Sánchez et al., 1988). One of the biological functions of these components is believed to be linked to the selection of a newborn's intestinal flora (Ribadeau-Dumas, 1983).

\section{IgG ABSORPTION IN THE NEWBORN CALF}

Colostrum should be fed immediately after a calf is born and not delayed to provide protective passive immunity (Fischer et al., 2018). Newborn calves have not yet developed their immune system at birth (Nocek et al., 1984; Stelwagen et al., 2009). It is important to feed newborns with first-milking colostrum because colostral concentrations of $\operatorname{IgG}, \mathrm{M}$, and A decrease at different rates as the number of milkings postpartum increases (Stott et al., 1981). Timing of colostrum feeding is crucial to achieve high IgG absorption rates. The transfer of immunoglobulins from colostrum to the bloodstream of the calf is due to a temporary ability to absorb proteins in the intestine during the first hours of life. Approximately $24 \mathrm{~h}$ after birth, the cells in the intestine can no longer absorb and transport these immunoglobulins or other large molecules. This perme- ability closure was reported by McCoy et al. (1970) in a study that demonstrated that feeding colostrum at $24 \mathrm{~h}$ after birth did not change the serum $\gamma$-globulin level. As a result, it can be suggested that the gut was impermeable to colostral proteins at that point and that feeding colostrum at $24 \mathrm{~h}$ after birth is unsuitable. Usually the percentage of total antibodies absorbed in the bloodstream, the AEA, from colostrum ranges from 20 to $35 \%$, even if a high-quality colostrum is provided (Quigley and Drewry, 1998; Jones and Heinrichs, 2006). However, AEA varies among studies, and some reports have shown values outside of this range. For example, Lago et al. (2018) reported a range from 32.6 to $76.9 \%$ with a mean of $35.9 \%$ for calves fed maternal colostrum with an IgG concentration of $63.6 \mathrm{~g} / \mathrm{L}$. Also, Halleran et al. (2017) reported a range between 10 and 50\% and no relationship between total amount of IgG fed and AEA. However, they estimated calf BW and used an estimated plasma volume of $7 \%$, both of which could have affected their conclusions. Fischer et al. (2018) stated that delaying colostrum feeding by 6 or $12 \mathrm{~h}$ affects IgG passive transfer and that delaying colostrum feeding in contrast to feeding it at birth might affect gut permeability closure and decrease AEA. Some of the major factors that contribute to the mass of $\operatorname{IgG}$ absorbed by calves are the quality (IgG concentration) and amount (volume fed) of colostrum provided after birth (Godden, 2008). In addition to colostrum feeding to ensure SPI in newborn calves, adequate management practices must be practiced to minimize morbidity rates (Quigley et al., 2017).

In general, immunoglobulins are absorbed in the small intestinal epithelium of a newborn, pass through the lymphatic system, and finally enter systemic circulation via the thoracic duct (Comline et al., 1951; Bush and Staley, 1980; Besser and Gay, 1994). There is a combination of immunoglobulin clearance and onset of endogenous production in a calf's system. It is believed that newborns clear approximately $70 \%$ of ingested IgG through the intestinal lumen (Besser et al., 1988). Furthermore, immunoglobulins have been found in the gastrointestinal tract where they function as antigen binders (Besser et al., 1988). It is believed that calves start their endogenous IgG synthesis between $36 \mathrm{~h}$ and 3 wk of age (Devery et al., 1979). However, it has been researched that colostrum-deprived calves or calves not fed sufficient colostrum start to produce antibodies earlier in life (Husband and Lascelles, 1975) and that they already have a cell-mediated immune response similar to an adult cow at approximately 2 wk of age (Barrington and Parish, 2001). Comline et al. (1951) cannulated newborn Jersey calves in the duodenum, cecum, and thoracic duct, and administered fat-free colostrum directly to the intestine to study the route of 
absorption of immunoglobulins. They found that globulins are not directly transported to the portal circulation, but rather transported in the lymph and then to the peripheral blood. Specifically, it is understood that immunoglobulin absorption in the intestine is nonselective and is accomplished by a pinocytosis mechanism (Besser and Gay, 1994). Staley et al. (1972) mentioned that the intestine has certain level of selectivity; however, they concluded that although the intestine of a newborn can absorb or is permeable to heterologous proteins, it does not absorb ferritin. Similarly, Bush and Staley (1980) also mentioned that immunoglobulin absorption in the intestine is done by an apical tubular system absorbing only certain substances. There are factors that have been shown to interfere with IgG. For example, bacterial contamination present in colostrum can affect absorption because bacteria can bind to this molecule and thus affect its absorption (Gelsinger et al., 2014). This issue has been addressed by heattreating colostrum, where it has been demonstrated that it increases serum IgG concentrations at $24 \mathrm{~h}$ in newborn calves (Gelsinger et al., 2014, 2015; Saldana et al., 2019). It also has to be considered that not all immunoglobulins enter or can be found in the systemic circulation, as some can take other routes rather than plasma or be excreted in feces (Matte et al., 1982).

\section{METHODS OF FEEDING COLOSTRUM}

Producers need to consider the amount of colostrum they feed to ensure SPI in newborn calves. To ensure sufficient colostrum consumption, producers should not rely on the colostrum a calf can suckle from its dam (McCoy et al., 1970) because it not possible to measure the volume and time after birth the calf consumed colostrum. This delay in time when a calf is able to suckle is crucial because delayed suckling for 2 to 6,7 to 12 , 13 to 24 , or 25 to 48 h has mortality rates of $5,8,11$, and 20\%, respectively (Margerison and Downey, 2005). It has been reported that 25 to $30 \%$ of calves fail to suckle from their dam by $6 \mathrm{~h}$, and approximately $20 \%$ fail to suckle by $18 \mathrm{~h}$ (Moran, 2012). This demonstrates how only allowing a calf to suckle colostrum from its dam could affect its FPI (Besser et al., 1991) due to failure of a calf to voluntarily consume adequate colostrum. Interestingly, Stott et al. (1979a) reported that rate of absorption and maximum IgG absorption were superior in calves that suckled colostrum from their dam compared with calves fed from a bottle. Stott et al. (1979a) and Selman et al. (1971) hypothesized that there is a mothering effect that is passed to the calf in the fresh colostrum suckling. This effect could act as a messenger factor that might stimulate the activity of absorptive cells in the intestinal epithelium; however, there is not sufficient evidence to support this (Stott et al., 1979a). Additionally, in most reports, calves that are allowed to only nurse their dam have lower serum IgG concentrations and are more susceptible to disease than hand-fed calves (Brignole and Stott, 1980; Nocek et al., 1984; Besser et al., 1991). Haines and Godden (2011) evaluated the effects of mothering by performing an artificial mothering that included verbal and physical stimulation to newborn calves. They reported no differences in IgG absorption between calves that received artificial mothering or not (15 and $13.9 \mathrm{mg} /$ $\mathrm{mL}$; respectively).

Maternal colostrum can be fed by nipple bottle, bucket, or esophageal feeder (Jones and Heinrichs, 2006). Using an esophageal feeder is often recommended due to the large volume of fluid required. The most common feeding method used to be hand-fed from a bucket or nipple bottle (64\%) and the least common was the use of esophageal feeder $(2.3 \%$; Heinrichs et al., 1994). More recent data from NAHMS (2014) reported that $81.6,15.7$ and $2.7 \%$ of heifer calves were fed via hand-feeding only (including via esophageal feeder), both hand-feeding and suckling dam, and suckling dam only, respectively. All types of colostrum feedings have the capacity to provide a newborn the necessary and sufficient amount of nutrients and immunoglobulins if the correct parameters of colostrum quality and volume fed are taken into account (Roy, 1972). However, there are risks with the use of an esophageal feeder with improper placement in the calf and damage to the esophagus, or, more importantly, liquid aspiration in the lungs (Jones and Heinrichs, 2006). Feeding colostrum via esophageal feeder to newborn calves has been reported to be a time-saving and optimum method to accomplish successful IgG passive transfer. (LateurRowet and Breukink, 1983; Elizondo-Salazar et al., 2011). However, one potential disadvantage linked to this method is that the esophageal groove reflex does not occur when calves are fed with esophageal feeders. Whenever calves do not experience the esophageal groove reflex, colostrum enters the forestomach before the abomasum and then enters the small intestine. In contrast, if a calf suckles from its dam or is fed via nipple bottle, the esophageal groove reflex occurs and the colostrum goes directly to the abomasum, resulting in a faster transport to the small intestine. However, when calves are fed via esophageal feeder, the passage of colostrum from the forestomach (reticulorumen) to the abomasum occurs within a few minutes and does not affect immunoglobulin absorption (Lateur-Rowet and Breukink, 1983). Elizondo-Salazar et al. (2011) conducted a study to compare if there were differences in IgG absorption between calves fed colostrum via nipple bottle or esophageal feeder. They found no differences 
in serum IgG concentration at $24 \mathrm{~h}$ or AEA rates, suggesting that using an esophageal feeder does not reduce IgG absorption. Similarly, Desjardins-Morrissette et al. (2018) did not find differences in IgG absorption when high-quality colostrum was fed either by esophageal feeder or nipple bottle, and neither esophageal feeder nor nipple-bottle feeding affected abomasal emptying to the small intestine. Besser et al. (1985) concluded that colostrum feeding with an esophageal feeder has a quick flow from the forestomach to the abomasum and small intestine, which provides an effective and sufficient absorption of immunoglobulins. Another study conducted by Besser et al. (1991) evaluated 3 methods of feeding colostrum to dairy calves and found that tube feeding was a good alternative to reach SPI. The study by Besser et al. (1991) observed 3 herds in which newborns were fed colostrum either from their dams, nipple-bottle feeding, or esophageal tube feeding. Failure of passive immunity (IgG concentration $<10 \mathrm{mg} /$ $\mathrm{mL}$ ) among the distinct methods was $61.4,19.3$, and $10.8 \%$, respectively. These results can be explained by the ability to feed a greater volume of colostrum with methods alternative to maternal suckling, ensuring SPI.

It is worth noting that in most situations when large amounts of colostrum are fed, AEA tends to decrease. This can be explained due to the suggestion that an upper limit may exist to the amount of IgG that can be absorbed in a certain time (Saldana et al., 2019). Lopez et al. (2020a) reported similar results where AEA decreased as more total IgG mass was fed with a large colostrum meal of $3.78 \mathrm{~L}$ at birth. Lopez et al. (2020a) also found that an upper limit of IgG absorption may exist due to decreased AEA when higher doses of IgG were fed along with colostrum containing higher amounts of total solids.

When colostrum reaches the abomasum, it forms a curd from the reaction of renin with casein and milk fat, which separates out the whey. Curd formation occurs in milk, colostrum, and CR or milk replacers that have casein and milk fat, as they are the molecules to which chymosin specifically binds (Yvon et al., 1984; Longenbach and Heinrichs, 1998). This curd formation is somewhat detrimental for digestion and absorption of IgG and other nutrients found in colostrum (Miyazaki et al., 2017). It is attributed to the fact that IgG is found in the whey portion of colostrum (Besser and Osborn, 1993) and permits a faster release to the intestine for absorption while leaving fat and casein in the abomasum for later absorption (Cruywagen et al., 1990). Data from Cabral et al. (2014) and Besser and Osborn (1993) suggest that casein competes with $\operatorname{IgG}$ for absorption in the intestinal tract, and, as a result, AEA of IgG may be negatively affected. Also, Davenport et al. (2000) demonstrated that the addi- tion of large amounts of casein $(>500 \mathrm{~g})$ in colostrum can affect IgG absorption rates, which again suggests that IgG absorption may be improved if casein is absent or in low amounts. Similarly, Lopez et al. (2020a) found that feeding a commercial CR that had its casein removed increased AEA from 24.4 to $40.1 \%$ in comparison to high-quality maternal colostrum $(106 \mathrm{~g} / \mathrm{L}$ of $\operatorname{IgG})$. Additionally, they reported that supplementing a low-quality maternal colostrum $(30 \mathrm{~g} / \mathrm{L}$ of immunoglobulins; low content of total solids) with a CR that had its casein removed, increased AEA up to $54.3 \%$. Although they could not specify the mechanism that elevated AEA above average, Lopez et al. (2020a) suggested that the low osmolality of this meal, reduced casein, and lower total amount of solids could have affected how IgG was absorbed. Cabral et al. (2014) suggested that the addition of $\mathrm{NaHCO}_{3}$ to $\mathrm{CR}$ can increase its coagulation properties due to the increase in casein content. It has been suggested that casein coagulation or curd formation could be beneficial to IgG absorption (Cabral et al., 2014; Miyazaki et al., 2017). However, when excessive amounts are present, it could increase colostrum osmolality. This results in a slower passage rate from the abomasum to the intestine, and thus a reduced abomasal emptying rate (Constable et al., 2009; Cabral et al., 2014; Burgstaller et al., 2017). Constable et al. (2009) demonstrated that the addition of an oral rehydration solution containing bicarbonate, acetate, and citrate contributes to increasing cow's milk osmolality, and thus decreases abomasal emptying rate. This could slow immunoglobulin absorption if they are trapped in the curd. Colostrum replacer osmolality can vary because of their different manufacturing techniques, but values around $300 \mathrm{mOsm}$ have been reported (Cabral et al., 2014), and Quigley et al. (2019) reported a mean osmolality value of $332 \mathrm{mOsm}$ for maternal colostrum. Usually mammalian (human) milk osmolality averages $300 \mathrm{mOsm} / \mathrm{kg}$ (Rochow et al., 2013). Osmolality increases as additional products are added to milk or colostrum; for example, the addition of $\mathrm{NaHCO}_{3}$ to $\mathrm{CR}$ increased its osmolality from 301 to 515 mOSm (Cabral et al., 2014), but it will vary with protein content and source (Burgstaller et al., 2017). Osmolality values for bovine milk range between 275 and $285 \mathrm{mOsm} / \mathrm{L}$, whereas some milk replacers go up to $600 \mathrm{mOsm} / \mathrm{L}$.

Analyzing the results from Saldana et al. (2019) related to the existence of an upper limit of IgG absorption leads to the assumption that a possible gut saturation might exist, which has been previously speculated but not demonstrated thoroughly. This concept was first suggested by Besser et al. (1985), where they stated that calves may have a physiological limitation for the amount of IgG they can absorb in determined 
volumes of colostrum fed. Besser et al. (1985) suggested that one possible mechanism for this effect could be a saturation of the macromolecular transport mechanism in charge of absorbing $\operatorname{IgG}$ molecules in the intestine. This possible saturation is related to the composition of colostrum of CR fed, including IgG and total solids concentration, but osmolality could play an important role.

\section{OVERCOMING COLOSTRUM SHORTAGES}

\section{Storage}

Due to the critical importance of colostrum to newborn calves, every dairy farm must have an adequate supply of high quality, disease-free colostrum available. When such colostrum cannot be provided by the dams, farms must have a supplementary strategy to ensure adequate provision of colostrum to the newborn calf. Storing excess colostrum offers an economical alternative. Colostrum can be stored by refrigerating or freezing, though it is usually kept frozen to maintain quality and prevent bacterial growth. Different storage methods affect colostrum quality due to varying effects on bacterial growth (Morrill et al., 2012). It is known that farms sometimes do not have proper colostrum storage protocols. If fresh colostrum is not fed within 2 $\mathrm{h}$ after collection, refrigeration at $4^{\circ} \mathrm{C}$ in small size containers can maintain its cellular components and immunoglobulin composition for a short time (Manohar et al., 1997). Colostrum left at ambient temperature has been shown to have a rapid increase in bacteria proliferation (Stewart et al., 2005), and Morrill et al. (2012) reported that refrigerated colostrum samples had a total plate count up to 1 million $\mathrm{cfu} / \mathrm{mL}$. Stewart et al. (2005) demonstrated that bacteria counts in colostrum are most often low at harvest from the cow, but transfer to buckets or storage containers are the steps where colostrum is often contaminated with bacteria. Most recommendations state that colostrum should not be kept more than $48 \mathrm{~h}$ under refrigeration as some bacteria can multiply by intermediate growth rates even under cold conditions (Stewart et al., 2005). This technique is only recommended as a short-term storage alternative because freezing colostrum is the best way to conserve it and can prevent nutrient and IgG content degradation for more than a year (Foley and Otterby, 1978; Davis and Drackley, 1998). In addition to bacteria proliferation, colostrum storage techniques have also been evaluated for any effects on calf serum IgG concentrations. Feeding pasteurized colostrum that has been previously frozen or feeding freshly harvested colostrum has resulted in calves having the highest serum $\operatorname{IgG}$ concentration in comparison to calves fed colostrum stored at 4,13 , or $22^{\circ} \mathrm{C}$ for $48 \mathrm{~h}$ (Cummins et al., 2017). As a result, fresh or previously frozen colostrum are both considered acceptable storage and feeding techniques (Holloway et al., 2001).

\section{Colostrum Replacer}

Early CR did not have $\geq 100 \mathrm{~g}$ of IgG per dose according to Quigley et al. (2001). As a result, other ingredients (i.e., dextrose, glycine, salt, emulsifier, lecithin, vitamin/mineral premix, potassium chloride, magnesium sulfate, and flavor) were added in an attempt to improve its nutritional value. Current CR products provide an exogenous source of IgG (Cabral et al., 2013), are made from lacteal, blood or serum, or egg sources (Quigley, 2004; Swan et al., 2007), but their nutritional composition varies due to the different manufacturing procedures (Quigley et al., 2002; Foster et al., 2006; Swan et al., 2007). Some producers use CR when they are not able to provide adequate maternal colostrum to their calves during periods where cows have diseases such as mastitis or milk pathogens such as Mycobacterium avium ssp. paratuberculosis, commonly known as Johne's disease (Pithua et al., 2009). Maternal colostrum can also be a source of Escherichia coli and bovine leukosis for a newborn calf, which can affect calf health (Cabral et al., 2013). Using CR products prevents FPI while reducing pathogen exposure because $\mathrm{CR}$ have a lower bacterial population than maternal colostrum (McGuirk and Collins, 2004; Foster et al., 2006). Overall, when colostrum is not available on a farm, CR could be an alternative due to easy storage and feeding preparation (Priestley et al., 2013), but it should not replace the reference standard meal of a high-quality colostrum (Cabral et al., 2013). One of the possible advantages of $\mathrm{CR}$ feeding is the ease of preparation, which can result in a faster colostrum feeding rather than thawing maternal colostrum from a colostrum bank on some farms. Nevertheless, it has been discussed about how CR products may lack antigen-specific antibodies that can protect newborn against farm-specific pathogens (Swan et al., 2007), yet no reported negative effects have been documented.

Multiple studies (e.g., Jones et al., 2004; Lago et al., 2018; Lopez et al., 2020a) have demonstrated that CR can be an alternative to feeding maternal colostrum to newborn calves. Jones et al. (2004) reported that the IgG concentration in blood plasma at $24 \mathrm{~h}$ was not different between calves fed maternal colostrum (means $\pm \mathrm{SD} ; 13.78 \pm 0.39 \mathrm{~g} / \mathrm{L}$ ) and calves fed the same mass of IgG from a CR $(13.96 \pm 0.38 \mathrm{~g} / \mathrm{L})$. Also, growth development measures (i.e., ADG, withers height, hip 
height, body length, and heart girth) did not differ between treatments. Nevertheless, one should consider that the immunoglobulins present in a CR can lack protection against farm-specific pathogens (Jones et al., 2004). Although maternal colostrum is the preferred feed, CR can be an acceptable alternative for newborn calves.

\section{IgG CONCENTRATION ANALYSIS}

\section{Reference Methods}

Serum IgG concentration can be determined by direct and indirect methods, but radial immunodiffusion (RID; a direct method) and ELISA (an indirect method) have been considered the reference standards for this analysis (Coons et al., 2012; Deelen et al., 2014; Wilm et al., 2018). Both of these methods have been considered an adequate method to identify calves with FPI (Dawes et al., 2002; Coons et al., 2012; Priestley et al., 2013). However, Gelsinger et al. (2015) evaluated the correlation of colostrum and serum IgG when analyzed either with ELISA or RID and found a weak correlation between RID and ELISA for plasma and nonheated colostrum. Additionally, Gelsinger et al. (2015) showed that ELISA analyses, in comparison with RID, provide lower IgG concentration results, but a direct comparison between both methods could not be drawn. In contrast, Dunn et al. (2018) reported a positive correlation between these methods for colostral $\left(\mathrm{R}^{2}=0.83\right)$ and serum IgG concentrations $\left(\mathrm{R}^{2}=0.97\right)$. Dunn et al. (2018) also recommended not to directly compare RID and ELISA results, though both methods provided consistent, replicable results. Overall, the only clear advantage of RID against ELISA is that it requires less extensive dilutions, which could contribute to the variation in results (Gelsinger et al., 2015b). This procedure developed by Fahey and McKelvey (1965) and Mancini et al. (1965) is specific for various proteins present in serum that react with their specific antibodies. The mode of action for this assay relies on the reaction between the antibody content in the well and the antigen in a serum sample. The proteins present in the sample diffuse in the well until equilibrium is reached (Guidry and Pearson, 1979). Afterward, a precipitin ring forms within $24 \mathrm{~h}$ at room temperature. The ring diameter is proportional to the concentration of the protein in the sample (Guidry and Pearson, 1979), and an $\mathrm{IgG}$ calculation can be done by a linear regression with the standards provided in the kit (Guidry and Pearson, 1979; Gelsinger et al., 2015b). In summary, this analysis works through the diffusion of the antigen with a specific antiserum that precipitates a ring around the well until equilibrium is reached at $24 \mathrm{~h}$.

\section{Indirect Methods}

An indirect method that is widely used is the measurement of serum total protein (STP) by refractometry, which gives an estimation of IgG from total protein in the serum (Deelen et al., 2014; Thornhill et al., 2015; Elsohaby et al., 2019). Serum total protein has been considered a good indicator of IgG concentration to predict calf morbidity (Naylor and Kronfeld, 1977; Naylor et al., 1977; Tyler et al., 1996; Weaver et al., 2000). This method has been widely used as an indirect measurement to predict FPI and IgG concentration because it measures total protein. Immunoglobulins contribute a large proportion of the total protein present in a newborn calf's bloodstream, which provides adequate estimates, and because nonimmunoglobulin proteins in serum remain constant (Calloway et al., 2002). The correlation of STP and IgG can vary in calves fed CR. This variation has been attributed to the different IgG to total protein ratios present in maternal colostrum and $\mathrm{CR}$, which affects the estimates of total protein a refractometer measures (Quigley et al., 2002). Overall, the mean ratio of $\mathrm{IgG}$ to protein in maternal colostrum ranges from 400 to $500 \mathrm{mg} / \mathrm{g}$ (Quigley et al., 2002).

Although Wilm et al. (2018) stated that STP is highly correlated with the RID, Quigley et al. (2002) and Lago et al. (2018) have mentioned that STP measurements for calves fed CR products might have erroneous estimates to identify FPI. Lopez et al. (2020a) found that mean STP levels in calves fed a low-casein CR were below the FPI threshold of $5.2 \mathrm{~g} / \mathrm{dL}$ even if their mean serum IgG were above $10 \mathrm{mg} / \mathrm{mL}$. Similarly, Quigley et al. (2002) and Lago et al. (2018) have found low STP when calves were fed CR. This suggests that calves still achieve adequate serum IgG concentrations even if their STP are low whenever they are fed low-casein CR. Lopez et al. (2020a) suggested that new STP cutoff points should be used to more accurately identify FPI in calves fed CR, especially when fed whey-based CR. Lopez et al. (2020a) and Quigley et al. (2002) reported that a STP cutoff point of $4.2 \mathrm{~g} / \mathrm{dL}$ is a better predictor of a serum IgG concentration of $10 \mathrm{mg} / \mathrm{mL}$ when calves are fed CR. Overall, more research is needed to correctly classify FPI or SPI in calves fed CR products.

\section{FAILURE OF PASSIVE IMMUNITY}

Failure of passive immunity is a condition considered for calves that have a serum IgG concentration $<10$ $\mathrm{mg} / \mathrm{mL}$ at $24 \mathrm{~h}$ (Besser et al., 1991; Furman-Fratczak et al., 2011; Shivley et al., 2018). In contrast, calves with a serum $\operatorname{IgG}$ concentration $>10 \mathrm{mg} / \mathrm{mL}$ at $24 \mathrm{~h}$ are considered as having a SPI (Quigley, 2004; Lombard et al., 2020). In addition, measuring serum IgG 
concentrations at $24 \mathrm{~h}$, STP is also an assay used to determine FPI in calves. Different STP concentration endpoints including $5.0,5.2$, or $5.5 \mathrm{~g} / \mathrm{dL}$ to determine FPI have been reported (Tyler et al., 1996; Donovan et al., 1998; Priestley et al., 2013). However, a metaanalysis conducted by Buczinski et al. (2018) concluded that STP cutoff points of 5.2 or $5.5 \mathrm{~g} / \mathrm{dL}$ are the most suitable to measure FPI. Buczinski et al. (2018) recommended that the threshold of $5.5 \mathrm{~g} / \mathrm{dL}$ could minimize the proportion of false negatives. A study conducted by Quigley et al. (2002) stated that the differences in nonimmunoglobulin protein contents between $\mathrm{CR}$ products and maternal colostrum affect consistent predictions of serum IgG levels by refractometry when calves are fed CR. As a result, it was concluded that a value of $4.9 \mathrm{~g} /$ $\mathrm{dL}$ was more suitable to be the endpoint to determine FTP in calves fed a CR instead of maternal colostrum. Quigley et al. (2002) suggested the inaccuracy of refractometry to estimate serum IgG concentrations. It may be recommended that current STP refractometry cutoff points should be further investigated to assess FPI rates in farms. The existence of external factors such as nutritional and environmental management strategies (i.e., sanitation, housing, and pathogen exposure) can be detrimental for calf health and development even if calves experience a successful passive transfer (Davis and Drackley, 1998; Swan et al., 2007).

\section{APPARENT EFFICIENCY OF ABSORPTION}

Apparent efficiency of absorption is a term used to explain the efficiency with which colostral IgG are absorbed. This is not a measure of total IgG absorbed; instead, it is an efficiency measurement of the fraction of total IgG mass fed present in the calf's blood system at $24 \mathrm{~h}$. Various factors affect AEA, including colostrum quality (IgG concentration), time at first feeding, feeding method, calf sex, calf birth BW, and hydration status, which affects plasma volume in the calf (Quigley et al., 1998; Godden et al., 2009b). The AEA formula commonly used is as follows: AEA = $\{$ birth weight $(\mathrm{kg}) \times 0.09 \times$ serum $\mathrm{IgG}(\mathrm{mg} / \mathrm{mL} 24$ h)]/total IgG fed $(\mathrm{g})\} \times 100$ [adapted from Quigley and Drewry (1998), Quigley et al. (2002), and Saldana et al. (2019)].

The 0.09 value in the formula presented accounts for the estimated plasma volume of a newborn calf $(9 \%$ of birth BW). However, this formula depends on the percentage of plasma assumed. Most studies rely on $9 \%$, which was used by Quigley et al. (1998), yet other studies have used $9.9 \%$ (Fischer et al., 2018) and 7\% (Halleran et al., 2017).

Besser et al. (1991) and Davis and Drackley (1998) mentioned that a minimum amount of $100 \mathrm{~g}$ of $\mathrm{IgG}$ should be provided to newborn calves to accomplish SPI, but calves fed 100 or even $110 \mathrm{~g}$ of IgG can still experience FPI. As a result, the minimum value of 100 $\mathrm{g}$ of $\mathrm{IgG}$ should be further investigated. For example, a scenario described by Quigley et al. (2002) demonstrated that if a calf is fed $100 \mathrm{~g}$ of IgG (assuming it has a $35 \%$ AEA, which is the highest value in the normal range of 20 to 35\%; Quigley and Drewry, 1998), it would have a predicted serum IgG concentration of 9.7 $\mathrm{mg} / \mathrm{mL}$, which is below the cutoff of $10 \mathrm{mg} / \mathrm{mL}$ used to determine FPI. As a result, Quigley et al. (2002) recommended a minimum of 150 to $200 \mathrm{~g}$ of $\mathrm{IgG}$ has to be provided to a newborn to prevent FPI.

Overall, excellent colostrum management is needed to adequately rear newborn calves. Various factors including but not limited to colostrum composition and quality, storage, absorption efficiency, and feeding method need to be considered. To verify if an adequate amount of IgG was fed to a calf, it is necessary to directly measure serum IgG concentration in the calf at $24 \mathrm{~h}$ of life. However, there are indirect methods to measure IgG, such as STP, that can be adequate when calves are fed maternal colostrum. Indirect methods may require different cutoff points for calves fed CR. Both methods, STP or serum IgG, have different cutoff points (5.2 or $5.5 \mathrm{~g} / \mathrm{dL}$ and $10 \mathrm{mg} / \mathrm{mL}$, respectively) that will determine if a calf exhibited SPI or FPI after colostrum ingestion. It is recommended to feed colostrum with a concentration $\geq 50 \mathrm{mg} / \mathrm{mL}$ of $\operatorname{IgG}$ and provide it within $2 \mathrm{~h}$ after birth. This quick feeding will permit the small intestine to absorb the desired proteins before its gradual permeability closure, which is believed to occur completely at $24 \mathrm{~h}$ after birth. Whenever high-quality colostrum is not available for immediate feeding, CR can be an alternate feed. However, these alternative products can only be considered as replacers if they contain a minimum of $100 \mathrm{~g}$ of $\mathrm{IgG}$ per dose and should not completely replace the standard feeding of maternal colostrum.

\section{SUMMARY}

Maternal colostrum is a highly nutritive feed that must be provided to a newborn at birth. It has a high level of immunoglobulins, which are proteins that develop a calf's immune system through passive transfer. There are various types of immunoglobulins in colostrum, but the IgG class is the primary one related to immunity transfer. To verify if an adequate amount of IgG was fed to a calf, it is necessary to directly measure serum IgG concentration at $24 \mathrm{~h}$ of life. There are indirect methods to measure IgG, such as STP or Brix \%, that can be adequate when calves are fed maternal colostrum. When calves are fed CR, different 
cutoff points may be required, and measuring serum IgG would be more accurate. Factors such as colostrum quality, which includes IgG concentration and bacteria levels, will help determine the amount of $\operatorname{IgG}$ found in a calf's bloodstream at $24 \mathrm{~h}$. It is recommended to feed colostrum with a concentration $\geq 50 \mathrm{mg} / \mathrm{mL}$ of $\operatorname{IgG}$ and provide it within $2 \mathrm{~h}$ after birth. This quick feeding will permit the small intestine to absorb the immunoglobulin proteins before its gradual permeability closure; complete closure occurs at $24 \mathrm{~h}$ after birth. When high-quality colostrum is not available for immediate feeding, CR can be an alternate feed.

\section{ACKNOWLEDGMENTS}

No external funding was received for this review. The authors have not stated any conflicts of interest.

\section{REFERENCES}

Abuelo, A., F. Cullens, A. Hanes, and J. L. Brester. 2021. Impact of 2 versus 1 colostrum meals on failure of transfer of passive immunity, pre-weaning morbidity and mortality, and performance of dairy calves in a large dairy herd. Animals (Basel) 11:782. https://doi .org/10.3390/ani11030782.

Andrew, S. M. 2001. Effect of composition of colostrum and transition milk from Holstein heifers on specificity rates of antibiotic residue tests. J. Dairy Sci. 84:100-106. https://doi.org/10.3168/jds.S0022 -0302(01)74457-8.

Barrington, G. M., T. E. Besser, W. C. Davis, C. C. Gay, J. J. Reeves, and T. B. McFadden. 1997. Expression of immunoglobulin $\mathrm{G}_{1}$ receptors by bovine mammary epithelial cells and mammary leukocytes. J. Dairy Sci. 80:86-93. https://doi.org/10.3168/jds.S0022 -0302(97) 75915-0.

Barrington, G. M., and S. M. Parish. 2001. Bovine neonatal immunology. Vet. Clin. North Am. Food Anim. Pract. 17:463-476. https:/ /doi.org/10.1016/S0749-0720(15)30001-3.

Baumrucker, C. R., and R. M. Bruckmaier. 2014. Colostrogenesis: IgG1 transcytosis mechanisms. J. Mammary Gland Biol. Neoplasia 19:103-117. https://doi.org/10.1007/s10911-013-9313-5.

Baumrucker, C. R., A. M. Burkett, A. L. Magliaro-Macrina, and C. D. Dechow. 2010. Colostrogenesis: Mass transfer of immunoglobulin $\mathrm{G}_{1}$ into colostrum. J. Dairy Sci. 93:3031-3038. https://doi.org/10 .3168/jds.2009-2963.

Besser, T. E., C. Gay, and L. Pritchett. 1991. Comparison of three methods of feeding colostrum to dairy calves. J. Am. Vet. Med. Assoc. 198:419-422.

Besser, T. E. 1993. Concentrations of passively acquired $\operatorname{IgG}_{1}$ antibodies in the intestinal lumen of the neonatal calf. Vet. Immunol. Immunopathol. 38:103-112. https://doi.org/10.1016/0165 -2427(93)90116-L.

Besser, T. E., A. E. Garmedia, T. C. McGuire, and C. C. Gay. 1985. Effect of colostral immunoglobulin $\mathrm{G}_{1}$ and immunoglobulin $\mathrm{M}$ concentrations on immunoglobulin absorption in calves. J. Dairy Sci. 68:2033-2037. https://doi.org/10.3168/jds.S0022-0302(85)81065 $-1$.

Besser, T. E., and C. C. Gay. 1994. The importance of colostrum to the health of the neonatal calf. Vet. Clin. North Am. Food Anim. Pract. 10:107-117. https://doi.org/10.1016/S0749-0720(15)30591 -0 .

Besser, T. E., T. C. McGuire, C. C. Gay, and L. C. Pritchett. 1988. Transfer of functional immunoglobulin $\mathrm{G}$ ( $\operatorname{IgG}$ ) antibody into the gastrointestinal tract accounts for IgG clearance in calves. J. Virol. 62:2234-2237. https://doi.org/10.1128/jvi.62.7.2234-2237.1988.
Besser, T. E., and D. Osborn. 1993. Effect of bovine serum albumin on passive transfer of immunoglobulin $\mathrm{G}_{1}$ to newborn calves. Vet. Immunol. Immunopathol. 37:321-327. https://doi.org/10.1016/0165 -2427(93)90203-G.

Blättler, U., H. M. Hammon, C. Morel, C. Philipona, A. Rauprich, V. Romé, I. Le Huërou-Luron, P. Guilloteau, and J. W. Blum. 2001 Feeding colostrum, its composition and feeding duration variably modify proliferation and morphology of the intestine and digestive enzyme activities of neonatal calves. J. Nutr. 131:1256-1263. https://doi.org/10.1093/jn/131.4.1256.

Blum, J. W., and C. R. Baumrucker. 2008. Insulin-like growth factors (IGFs), IGF binding proteins, and other endocrine factors in milk: Role in the newborn. Adv. Exp. Med. Biol. 606:397-422. https:// doi.org/10.1007/978-0-387-74087-4_16.

Brandon, M. R., D. L. Watson, and A. K. Lascelles. 1971. The mechanism of transfer of immunoglobulins into mammary secretions of cows. Aust. J. Exp. Biol. Med. Sci. 49:613-623. https://doi.org/10 .1038/icb.1971.67.

Brignole, T. J., and G. H. Stott. 1980. Effect of suckling followed by bottle feeding colostrum on immunoglobulin absorption and calf survival. J. Dairy Sci. 63:451-456. https://doi.org/10.3168/jds .S0022-0302(80)82952-3.

Broughton, C. W., and J. G. Lecce. 1970. Electron-microscopic studies of the jejunal epithelium from neonatal pigs fed different diets. J. Nutr. 100:445-449. https://doi.org/10.1093/jn/100.4.445.

Buczinski, S., E. Gicquel, G. Fecteau, Y. Takwoingi, M. Chigerwe, and J. Vandeweerd. 2018. Systematic review and meta-analysis of diagnostic accuracy of serum refractometry and brix refractometry for the diagnosis of inadequate transfer of passive immunity in calves. J. Vet. Intern. Med. 32:474-483. https://doi.org/10.1111/ jvim. 14893.

Bulgari, O., A. M. Caroli, S. Chessa, R. Rizzi, and C. Gigliotti. 2013. Variation of vitamin D in cow's milk and interaction with 3-lactoglobulin. Molecules 18:10122-10131. https://doi.org/10 $.3390 /$ molecules 180910122 .

Burgstaller, J., T. Wittek, and G. W. Smith. 2017. Invited review: Abomasal emptying in calves and its potential influence on gastro-intestinal disease. J. Dairy Sci. 100:17-35. https://doi.org/10 .3168/jds.2016-10949.

Bush, L. J., M. A. Aguilera, G. D. Adams, and E. W. Jones. 1971. Absorption of colostral immunoglobulins by newborn dairy calves. J. Dairy Sci. 54:1547-1549. https://doi.org/10.3168/jds.S0022 -0302(71)86063-0.

Bush, L. J., and T. E. Staley. 1980. Absorption of colostral immunoglobulins in newborn calves. J. Dairy Sci. 63:672-680. https://doi .org/10.3168/jds.S0022-0302(80)82989-4.

Butler, J., B. Larson, and V. Smith. 1974. Immunoglobulins of the mammary secretions in lactation. The Iowa State University Press.

Butler, J. E. 1969. Bovine immunoglobulins: A review. J. Dairy Sci. 52:1895-1909. https://doi.org/10.3168/jds.S0022-0302(69)86871 -2 .

Butler, J. E. 1983. Bovine immunoglobulins: An augmented review. Vet. Immunol. Immunopathol. 4:43-152. https://doi.org/10.1016/ 0165-2427(83)90056-9.

Cabral, R. G., M. A. Cabral, C. E. Chapman, E. J. Kent, D. M. Haines, and P. S. Erickson. 2014. Colostrum replacer feeding regimen, addition of sodium bicarbonate, and milk replacer: The combined effects on absorptive efficiency of immunoglobulin $\mathrm{G}$ in neonatal calves. J. Dairy Sci. 97:2291-2296. https://doi.org/10.3168/ jds.2013-7007.

Cabral, R. G., C. E. Chapman, and P. S. Erickson. 2013. Review: Colostrum supplements and replacers for dairy calves. Prof. Anim. Sci. 29:449-456. https://doi.org/10.15232/S1080-7446(15)30265-5.

Calloway, C. D., J. W. Tyler, R. K. Tessman, D. Hostetler, and J. Holle. 2002. Comparison of refractometers and test endpoints in the measurement of serum protein concentration to assess passive transfer status in calves. J. Am. Vet. Med. Assoc. 221:1605-1608. https://doi.org/10.2460/javma.2002.221.1605.

Chigerwe, M., J. W. Tyler, J. R. Middleton, J. N. Spain, J. S. Dill, and B. J. Steevens. 2008. Comparison of four methods to assess 
colostral IgG concentration in dairy cows. J. Am. Vet. Med. Assoc. 233:761-766. https://doi.org/10.2460/javma.233.5.761.

Comline, R. S., H. E. Roberts, and D. A. Titchen. 1951. Route of absorption of colostrum globulin in the newborn animal. Nature 167:561-562. https://doi.org/10.1038/167561a0.

Constable, P. D., W. Grünberg, and L. Carstensen. 2009. Comparative effects of two oral rehydration solutions on milk clotting, abomasal luminal $\mathrm{pH}$, and abomasal emptying rate in suckling calves. J. Dairy Sci. 92:296-312. https://doi.org/10.3168/jds.2008-1462.

Coons, D. M., K. A. Thompson, N. Lamberskiand, and M. Chigerwe. 2012. Quantitative indirect ELISA-based method for the measurement of serum IgG in springbok calves. Int. J. Appl. Res. Vet. Med. 10:142-146.

Cruywagen, C. W., G. J. Brisson, and H. H. Meissner. 1990. Casein curd-forming ability and abomasal retention of milk replacer components in young calves. J. Dairy Sci. 73:1578-1585. https://doi .org/10.3168/jds.S0022-0302(90)78828-5.

Cummins, C., D. P. Berry, J. P. Murphy, I. Lorenz, and E. Kennedy. 2017. The effect of colostrum storage conditions on dairy heifer calf serum immunoglobulin G concentration and preweaning health and growth rate. J. Dairy Sci. 100:525-535. https://doi .org/10.3168/jds.2016-10892.

Cuttance, E. L., W. Mason, R. Laven, and C. Phyn. 2019. Relationships between failure of passive transfer and subsequent mortality, bodyweights and lactation performance in 12-36 month old heifers on pasture-based, seasonal calving dairy farms in New Zealand. Vet. J. 251:105348. https://doi.org/10.1016/j.tvjl.2019.105348.

Dairy Calf and Heifer Association. 2010. Gold Standards. Accessed Jul. 23, 2021. http://haasnutrition.com/wp-content/uploads/ 2015/09/DCHA_GoldStandards_high-res_122016.pdf.

Davenport, D. F., J. D. Quigley III, J. E. Martin, J. A. Holt, and J. D. Arthington. 2000. Addition of casein or whey protein to colostrum or a colostrum supplement product on absorption ofIgG in neonatal calves. J. Dairy Sci. 83:2813-2819. https://doi.org/10.3168/jds .S0022-0302(00)75180-0.

Davis, C. L., and J. K. Drackley. 1998. The development, nutrition, and management of the young calf. Vol. Ames. Iowa State University Press.

Dawes, M. E., J. W. Tyler, D. Hostetler, J. Lakritz, and R. Tessman. 2002. Evaluation of a commercially available immunoassay for assessing adequacy of passive transfer in calves. J. Am. Vet. Med. Assoc. 220:791-793. https://doi.org/10.2460/javma.2002.220.791.

Deelen, S. M., T. L. Ollivett, D. M. Haines, and K. E. Leslie. 2014 Evaluation of a Brix refractometer to estimate serum immunoglobulin G concentration in neonatal dairy calves. J. Dairy Sci. 97:3838-3844. https://doi.org/10.3168/jds.2014-7939.

DeNise, S. K., J. D. Robison, G. H. Stott, and D. V. Armstrong. 1989. Effects of passive immunity on subsequent production in dairy heifers. J. Dairy Sci. 72:552-554. https://doi.org/10.3168/ jds.S0022-0302(89)79140-2.

Desjardins-Morrissette, M., J. K. van Niekerk, D. Haines, T. Sugino, M. Oba, and M. A. Steele. 2018. The effect of tube versus bottle feeding colostrum on immunoglobulin G absorption, abomasal emptying, and plasma hormone concentrations in newborn calves. J. Dairy Sci. 101:4168-4179. https://doi.org/10.3168/jds.2017 -13904 .

Devery, J. E., C. L. Davis, and B. L. Larson. 1979. Endogenous production of immunoglobulin IgG1 in newborn calves. J. Dairy Sci. 62:1814-1818. https://doi.org/10.3168/jds.S0022-0302(79)83504 $-3$.

Dewell, R. D., L. L. Hungerford, J. E. Keen, W. W. Laegreid, D. D. Griffin, G. P. Rupp, and D. M. Grotelueschen. 2006. Association of neonatal serum immunoglobulin $\mathrm{G}_{1}$ concentration with health and performance in beef calves. J. Am. Vet. Med. Assoc. 228:914-921. https://doi.org/10.2460/javma.228.6.914.

Donovan, G. A., I. R. Dohoo, D. M. Montgomery, and F. L. Bennett. 1998. Associations between passive immunity and morbidity and mortality in dairy heifers in Florida, USA. Prev. Vet. Med. 34:3146. https://doi.org/10.1016/S0167-5877(97)00060-3.

Dunn, A., C. Duffy, A. Gordon, S. Morrison, A. Argüello, M. Welsh, and B. Earley. 2018. Comparison of single radial immunodiffusion and ELISA for the quantification of immunoglobulin $\mathrm{G}$ in bovine colostrum, milk and calf sera. J. Appl. Anim. Res. 46:758-765. https://doi.org/10.1080/09712119.2017.1394860.

Elizondo-Salazar, J. A., B. M. Jayarao, and A. J. Heinrichs. 2010. Effect of heat treatment of bovine colostrum on bacterial counts, viscosity, and immunoglobulin G concentration. J. Dairy Sci. 93:961-967. https://doi.org/10.3168/jds.2009-2388.

Elizondo-Salazar, J. A., C. M. Jones, and A. J. Heinrichs. 2011. Feeding colostrum with an esophageal feeder does not reduce immunoglobulin G absorption in neonatal dairy heifer calves. Prof. Anim. Sci. 27:561-564. https://doi.org/10.15232/S1080-7446(15)30539-8.

Elsohaby, I., J. T. McClure, M. Cameron, L. C. Heider, and G. P. Keefe. 2017. Rapid assessment of bovine colostrum quality: How reliable are transmission infrared spectroscopy and digital and optical refractometers? J. Dairy Sci. 100:1427-1435. https://doi.org/ $10.3168 /$ jds.2016-11824.

Elsohaby, I., J. T. McClure, L. A. Waite, M. Cameron, L. C. Heider, and G. P. Keefe. 2019. Using serum and plasma samples to assess failure of transfer of passive immunity in dairy calves. J. Dairy Sci. 102:567-577. https://doi.org/10.3168/jds.2018-15070.

Fahey, J. L., and E. M. McKelvey. 1965. Quantitative determination of serum immunoglobulins in antibody-agar plates. J. Immunol. $94: 84$.

Fischer, A. J., Y. Song, Z. He, D. M. Haines, L. L. Guan, and M. A. Steele. 2018. Effect of delaying colostrum feeding on passive transfer and intestinal bacterial colonization in neonatal male Holstein calves. J. Dairy Sci. 101:3099-3109. https://doi.org/10.3168/jds 2017-13397.

Fischer-Tlustos, A. J., K. Hertogs, J. K. van Niekerk, M. Nagorske, D. M. Haines, and M. A. Steele. 2020. Oligosaccharide concentrations in colostrum, transition milk, and mature milk of primi- and multiparous Holstein cows during the first week of lactation. J. Dairy Sci. 103:3683-3695. https://doi.org/10.3168/jds.2019-17357.

Foley, J. A., and D. E. Otterby. 1978. Availability, storage, treatment, composition, and feeding value of surplus colostrum: A review. J. Dairy Sci. 61:1033-1060. https://doi.org/10.3168/jds.S0022 -0302(78)83686-8.

Foster, D. M., G. W. Smith, T. R. Sanner, and G. V. Busso. 2006. Serum IgG and total protein concentrations in dairy calves fed two colostrum replacement products. J. Am. Vet. Med. Assoc. 229:1282-1285. https://doi.org/10.2460/javma.229.8.1282.

Frenyo, V. L., J. E. Butler, R. A. Wilson, and J. Kavanagh. 1987. The transport and metabolism of bovine IgM. Mol. Immunol. 24:207219. https://doi.org/10.1016/0161-5890(87)90138-6.

Furman-Fratczak, K., A. Rzasa, and T. Stefaniak. 2011. The influence of colostral immunoglobulin concentration in heifer calves' serum on their health and growth. J. Dairy Sci. 94:5536-5543. https:// doi.org/10.3168/jds.2010-3253.

Gelsinger, S. L., S. M. Gray, C. M. Jones, and A. J. Heinrichs. 2014. Heat treatment of colostrum increases immunoglobulin G absorption efficiency in high-, medium-, and low-quality colostrum. J. Dairy Sci. 97:2355-2360. https://doi.org/10.3168/jds.2013-7374.

Gelsinger, S. L., C. M. Jones, and A. J. Heinrichs. 2015. Effect of colostrum heat treatment and bacterial population on immunoglobulin $\mathrm{G}$ absorption and health of neonatal calves. J. Dairy Sci. 98:4640-4645. https://doi.org/10.3168/jds.2014-8790.

Gelsinger, S. L., A. M. Smith, C. M. Jones, and A. J. Heinrichs. 2015b. Technical note: Comparison of radial immunodiffusion and ELISA for quantification of bovine immunoglobulin $\mathrm{G}$ in colostrum and plasma. J. Dairy Sci. 98:4084-4089. https://doi.org/10.3168/jds .2014-8491.

Godden, S. 2008. Colostrum management for dairy calves. Vet. Clin. North Am. Food Anim. Pract. 24:19-39. https://doi.org/10.1016/ j.cvfa.2007.10.005.

Godden, S. M., D. M. Haines, and D. Hagman. 2009a. Improving passive transfer of immunoglobulins in calves. I: Dose effect of feeding a commercial colostrum replacer. J. Dairy Sci. 92:1750-1757. https://doi.org/10.3168/jds.2008-1846.

Godden, S. M., D. M. Haines, K. Konkol, and J. Peterson. 2009b. Improving passive transfer of immunoglobulins in calves. II: In- 
teraction between feeding method and volume of colostrum fed. J. Dairy Sci. 92:1758-1764. https://doi.org/10.3168/jds.2008-1847.

Godden, S. M., J. E. Lombard, and A. R. Woolums. 2019. Colostrum management for dairy calves. Vet. Clin. North Am. Food Anim. Pract. 35:535-556. https://doi.org/10.1016/j.cvfa.2019.07.005.

Gopal, P. K., and H. S. Gill. 2000. Oligosaccharides and glycoconjugates in bovine milk and colostrum. Br. J. Nutr. 84(Suppl 1):S69S74. https://doi.org/10.1017/S0007114500002270.

Guidry, A. J., and R. E. Pearson. 1979. Improved methodology for quantitative determination of serum and milk proteins by single radial immunodiffusion. J. Dairy Sci. 62:1252. https://doi.org/10 .3168/jds.S0022-0302(79)83408-6.

Haines, D. M., and S. M. Godden. 2011. Short communication: improving passive transfer of immunoglobulins in calves. III. Effect of artificial mothering. J. Dairy Sci. 94:1536-1539. https://doi.org/ 10.3168/jds.2010-3679.

Hallberg, J. W., K. J. Dame, S. T. Chester, C. C. Miller, L. K. Fox, J. W. Pankey, S. C. Nickerson, and L. J. Weaver. 1995. The visual appearance and somatic cell count of mammary secretions collected from primigravid heifers during gestation and early postpartum. J. Dairy Sci. 78:1629-1636. https://doi.org/10.3168/jds .S0022-0302(95)76787-X.

Halleran, J., H. J. Sylvester, and D. K. Foster. 2017. Apparent efficiency of colostral immunoglobulin G absorption in Holstein heifers. J. Dairy Sci. 100:3282-3286. https://doi.org/10.3168/jds.2016-11904.

Hammon, H. M., W. Liermann, D. Frieten, and C. Koch. 2020. Review: Importance of colostrum supply and milk feeding intensity on gastrointestinal and systemic development in calves. Animal 14(S1):s133-s143. https://doi.org/10.1017/S1751731119003148.

Hammon, H. M., I. A. Zanker, and J. W. Blum. 2000. Delayed colostrum feeding affects IgF-I and insulin plasma concentrations in neonatal calves. J. Dairy Sci. 83:85-92. https://doi.org/10.3168/ jds.S0022-0302(00)74859-4.

Heinrichs, A. J., C. M. Jones, P. S. Erickson, H. Chester-Jones, and J. L. Anderson. 2020. Symposium review: Colostrum management and calf nutrition for profitable and sustainable dairy farms. J. Dairy Sci. 103:5694-5699. https://doi.org/10.3168/jds.2019-17408.

Heinrichs, A. J., S. J. Wells, H. S. Hurd, G. W. Hill, and D. A. Dargatz. 1994. The National Dairy Heifer Evaluation Project: A profile of heifer management practices in the United States. J. Dairy Sci. 77:1548-1555. https://doi.org/10.3168/jds.S0022-0302(94)77096 $-\mathrm{X}$.

Hernández-Castellano, L. E., A. M. Almeida, N. Castro, and A. Arguello. 2014. The colostrum proteome, ruminant nutrition and immunity: A review. Curr. Protein Pept. Sci. 15:64-74. https://doi .org/10.2174/1389203715666140221124622.

Holloway, N. M., J. W. Tyler, J. Lakritz, S. L. Carlson, and J. Holle. 2001. Serum immunoglobulin G concentrations in calves fed fresh and frozen colostrum. J. Am. Vet. Med. Assoc. 219:357-359. https: //doi.org/10.2460/javma.2001.219.357.

Houser, B. A., S. C. Donaldson, S. I. Kehoe, A. J. Heinrichs, and B. M. Jayarao. 2008. A survey of bacteriological quality and the occurrence of Salmonella in raw bovine colostrum. Foodborne Pathog. Dis. 5:853-858. https://doi.org/10.1089/fpd.2008.0141.

Husband, A. J., and A. K. Lascelles. 1975. Antibody responses to neonatal immunisation in calves. Res. Vet. Sci. 18:201-207. https: //doi.org/10.1016/S0034-5288(18)33614-2.

Jenness, R. 1982. Inter-species comparison of milk proteins. Pages 87 114 in Developments in Dairy Chemistry-1. Proteins. P. F. Fox, ed. Applied Science Publishers.

Johnson, J. L., S. M. Godden, T. Molitor, T. Ames, and D. Hagman. 2007. Effects of feeding heat-treated colostrum on passive transfer of immune and nutritional parameters in neonatal dairy calves. J. Dairy Sci. 90:5189-5198. https://doi.org/10.3168/jds.2007-0219.

Jones, C. M., and A. J. Heinrichs. 2006. Calf Care. W. D. Hoard \& Sons Company.

Jones, C. M., R. E. James, J. D. Quigley III, and M. L. McGilliard. 2004. Influence of pooled colostrum or colostrum replacement on $\mathrm{IgG}$ and evaluation of animal plasma in milk replacer. J. Dairy Sci. 87:1806-1814. https://doi.org/10.3168/jds.S0022-0302(04)73337 -8 .
Kehoe, S. I., B. M. Jayarao, and A. J. Heinrichs. 2007. A survey of bovine colostrum composition and colostrum management practices on Pennsylvania dairy farms. J. Dairy Sci. 90:4108-4116. https:// doi.org/10.3168/jds.2007-0040.

Kertz, A. F., T. M. Hill, J. D. Quigley III, A. J. Heinrichs, J. G. Linn, and J. K. Drackley. 2017. A 100-year review: Calf nutrition and management. J. Dairy Sci. 100:10151-10172. https://doi.org/10 $.3168 / j d s .2017-13062$.

Klein, J. 1982. Page 342 in Immunology: The Science of Self-Nonself Discrimination. Wiley.

Lacy-Hulbert, S. J., M. W. Woolford, G. Nicholas, C. G. Prosser, and K. Stelwagen. 1999. Effect of milking frequency and pasture intake on milk yield and composition of late lactation cows. J. Dairy Sci. 82:1232-1239. https://doi.org/10.3168/jds.S0022-0302(99)75346 -4 .

Lago, A., M. Socha, A. Geiger, D. Cook, N. Silva-del-Río, C. Blanc, R. Quesnell, and C. Leonardi. 2018. Efficacy of colostrum replacer versus maternal colostrum on immunological status, health, and growth of preweaned dairy calves. J. Dairy Sci. 101:1344-1354. https://doi.org/10.3168/jds.2017-13032.

Larson, B. L. 1992. Proteins. Pages 231-254 in Advanced Dairy Chemistry. Elsevier.

Larson, B. L., H. L. Heary Jr., and J. E. Devery. 1980. Immunoglobulin production and transport by the mammary gland. J. Dairy Sci 63:665-671. https://doi.org/10.3168/jds.S0022-0302(80)82988-2.

Lateur-Rowet, H. J., and H. J. Breukink. 1983. The failure of the oesophageal groove reflex, when fluids are given with an oesophageal feeder to newborn and young calves. Vet. Q. 5:68-74. https://doi .org/10.1080/01652176.1983.9693874.

Lecce, J. G., and D. O. Morgan. 1962. Effect of dietary regimen on cessation of intestinal absorption of large molecules (closure) in neonatal pigs and lambs. J. Nutr. 78:263-268. https://doi.org/10 $.1093 /$ jn/78.3.263.

Lilius, E. M., and P. Marnila. 2001. The role of colostral antibodies in prevention of microbial infections. Curr. Opin. Infect. Dis 14:295-300. https://doi.org/10.1097/00001432-200106000-00008.

Lombard, J., N. Urie, F. Garry, S. Godden, J. Quigley, T. Earleywine, S. McGuirk, D. Moore, M. Branan, M. Chamorro, G. Smith, C. Shivley, D. Catherman, D. Haines, A. J. Heinrichs, R. James, J. Maas, and K. Sterner. 2020. Consensus recommendations on calf- and herd-level passive immunity in dairy calves in the United States. J. Dairy Sci. 103:7611-7624. https://doi.org/10.3168/jds 2019-17955.

Longenbach, J. I., and A. J. Heinrichs. 1998. A review of the importance and physiological role of curd formation in the abomasum of young calves. Anim. Feed Sci. Technol. 73:85-97. https://doi.org/ 10.1016/S0377-8401(98)00130-8.

Lopez, A. J., C. M. Jones, A. J. Geiger, and A. J. Heinrichs. 2020a. Comparison of immunoglobulin $\mathrm{G}$ absorption in calves fed maternal colostrum, a commercial whey-based colostrum replacer, or supplemented maternal colostrum. J. Dairy Sci. 103:4838-4845. https://doi.org/10.3168/jds.2019-17949.

Lopez, A. J., C. M. Jones, A. J. Geiger, and A. J. Heinrichs. 2020b. Short communication: Variation in serum immunoglobulin G concentrations from birth to 112 days of age in Holstein calves fed a commercial colostrum replacer or maternal colostrum. J. Dairy Sci. 103:7535-7539.

Lora, I., F. Gottardo, B. Contiero, B. D. Ava, L. Bonfanti, A. Stefani, and A. Barberio. 2018. Association between passive immunity and health status of dairy calves under 30 days of age. Prev. Vet. Med. 152:12-15. https://doi.org/10.1016/j.prevetmed.2018.01.009.

Macdougall, D. F., and W. Mulligan. 1969. The distribution and metabolism of fast IgG immunoglobulin in the neonatal calf. J. Physiol. 201:77P-78P.

Mancini, G., A. O. Carbonara, and J. F. Heremans. 1965. Immunochemical quantitation of antigens by single radial immunodiffusion. Immunochemistry 2:235-254. https://doi.org/10.1016/0019 -2791(65)90004-2

Mann, S., G. Curone, T. L. Chandler, P. Moroni, J. Cha, R. Bhawal, and S. Zhang. 2020. Heat treatment of bovine colostrum: I. Effects on bacterial and somatic cell counts, immunoglobulin, insulin, and 
IGF-I concentrations, as well as the colostrum proteome. J. Dairy Sci. 103:9368-9383. https://doi.org/10.3168/jds.2020-18618.

Mann, S., F. A. Leal Yepes, T. R. Overton, A. L. Lock, S. V. Lamb, J. J. Wakshlag, and D. V. Nydam. 2016. Effect of dry period dietary energy level in dairy cattle on volume, concentrations of immunoglobulin G, insulin, and fatty acid composition of colostrum. J. Dairy Sci. 99:1515-1526. https://doi.org/10.3168/jds.2015-9926.

Manohar, A. A., M. Williamson, and G. V. Koppikar. 1997. Effect of storage of colostrum in various containers. Indian Pediatr. 34:293295.

Margerison, J., and N. Downey. 2005. Guidelines for optimal dairy heifer rearing and herd performance P. C. Garnsworthy, ed. Nottingham University Press, London, UK.

Marnila, P., and H. Korhonen. 2002. Colostrum. Pages 591-597 in Encyclopedia of Dairy Sciences. J. W. Fuquay, P. F. Fox, and P. L. H. McSweeney, ed. Academic Press, London, UK.

Martín, M.-J., S. Martín-Sosa, and P. Hueso. 2002. Binding of milk oligosaccharides by several enterotoxigenic Escherichia coli strains isolated from calves. Glycoconj. J. 19:5-11. https://doi.org/10 $.1023 / \mathrm{A}: 1022572628891$.

Matte, J. J., C. L. Girard, J. R. Seoane, and G. J. Brisson. 1982. Absorption of colostral immunoglobulin G in the newborn calf. J. Dairy Sci. 65:1765-1770. https://doi.org/10.3168/jds.S0022 -0302(82)82414-4.

McCoy, G. C., J. K. Reneau, A. G. Hunter, and J. B. Williams. 1970. Effects of diet and time on blood serum proteins in the newborn calf. J. Dairy Sci. 53:358-362. https://doi.org/10.3168/jds.S0022 -0302(70)86209-9.

McGrath, B. A., P. F. Fox, P. L. H. McSweeney, and A. L. Kelly. 2016. Composition and properties of bovine colostrum: A review. Dairy Sci. Technol. 96:133-158. https://doi.org/10.1007/s13594 $-015-0258-\mathrm{x}$

McGuirk, S. M., and M. Collins. 2004. Managing the production, storage, and delivery of colostrum. Vet. Clin. North Am. Food Anim. Pract. 20:593-603. https://doi.org/10.1016/j.cvfa.2004.06.005.

Miyazaki, T., K. Okada, and M. Miyazaki. 2017. Short communication: Neonatal calves coagulate first-milking colostrum and produce a large curd for efficient absorption of immunoglobulins after first ingestion. J. Dairy Sci. 100:7262-7270. https://doi.org/10 $.3168 /$ jds. 2017-12808.

Moore, M., J. W. Tyler, M. Chigerwe, M. E. Dawes, and J. R. Middleton. 2005. Effect of delayed colostrum collection on colostral IgG concentration in dairy cows. J. Am. Vet. Med. Assoc. 226:13751377. https://doi.org/10.2460/javma.2005.226.1375.

Moran, J. 2012. Rearing young stock on tropical dairy farms in Asia. CSIRO Publishing.

Morin, D. E., S. V. Nelson, E. D. Reid, D. W. Nagy, G. E. Dahl, and P. D. Constable. 2010. Effect of colostral volume, interval between calving and first milking, and photoperiod on colostral IgG concentrations in dairy cows. J. Am. Vet. Med. Assoc. 237:420-428. https://doi.org/10.2460/javma.237.4.420.

Morin, M. P., J. Dubuc, P. Freycon, and S. Buczinski. 2021a. A calflevel study on colostrum management practices associated with adequate transfer of passive immunity in Québec dairy herds. J. Dairy Sci. 104:4904-4913. https://doi.org/10.3168/jds.2020-19475.

Morin, M. P., J. Dubuc, P. Freycon, and S. Buczinski. 2021b. A herdlevel study on colostrum management factors associated with the prevalence of adequate transfer of passive immunity in Québec dairy herds. J. Dairy Sci. 104:4914-4922. https://doi.org/10.3168/ jds.2020-19476.

Morrill, K. M., E. Conrad, A. Lago, J. Campbell, J. Quigley, and H. Tyler. 2012. Nationwide evaluation of quality and composition of colostrum on dairy farms in the United States. J. Dairy Sci. 95:3997-4005. https://doi.org/10.3168/jds.2011-5174.

Morrissey, P. A., and T. R. Hill. 2009. Fat-soluble vitamins and vitamin $\mathrm{C}$ in milk and milk products. Pages 527-572 in Advanced dairy chemistry: Lactose, water, salts and minor constituents. Vol. 3. 3rd ed. P. F. Fox and P. H. L. McSweeney, ed. Springer.

Murphy, J. M., J. V. Hagey, and M. Chigerwe. 2014. Comparison of serum immunoglobulin $\mathrm{G}$ half-life in dairy calves fed colostrum, colostrum replacer or administered with intravenous bovine plasma. Vet. Immunol. Immunopathol. 158:233-237. https://doi.org/ 10.1016/j.vetimm.2014.01.008.

NAHMS. 2014. Dairy Cattle Management Practices in the United States. USDA:APHIS.

Naylor, J. M., and D. S. Kronfeld. 1977. Refractometry as a measure of the immunoglobulin status of the newborn dairy calf: comparison with the zinc sulfate turbidity test and single radial immunodiffusion. Am. J. Vet. Res. 38:1331-1334.

Naylor, J. M., D. S. Kronfeld, S. Bech-Nielsen, and R. C. Bartholomew. 1977. Plasma total protein measurement for prediction of disease and mortality in calves. J. Am. Vet. Med. Assoc. 171:635-638.

Newby, T. J., C. R. Stokes, and F. J. Bourne. 1982. Immunological activities of milk. Vet. Immunol. Immunopathol. 3:67-94. https:// doi.org/10.1016/0165-2427(82)90032-0.

Nguyen, D.-A. D., and M. C. Neville. 1998. Tight junction regulation in the mammary gland. J. Mammary Gland Biol. Neoplasia 3:233-246. https://doi.org/10.1023/A:1018707309361.

Nocek, J. E., D. G. Braund, and R. G. Warner. 1984. Influence of neonatal colostrum administration, immunoglobulin, and continued feeding of colostrum on calf gain, health, and serum protein. J. Dairy Sci. 67:319-333. https://doi.org/10.3168/jds.S0022 $-0302(84) 81305-3$.

Ontsouka, C. E., R. M. Bruckmaier, and J. W. Blum. 2003. Fractionized milk composition during removal of colostrum and mature milk. J. Dairy Sci. 86:2005-2011. https://doi.org/10.3168/jds .S0022-0302(03)73789-8.

Osaka, I., Y. Matsui, and F. Terada. 2014. Effect of the mass of immunoglobulin (Ig) G intake and age at first colostrum feeding on serum IgG concentration in Holstein calves. J. Dairy Sci. 97:66086612. https://doi.org/10.3168/jds.2013-7571.

Oyeniyi, O. O., and A. G. Hunter. 1978. Colostral constituents including immunoglobulins in the first three milkings postpartum. J. Dairy Sci. 61:44-48. https://doi.org/10.3168/jds.S0022 $-0302(78) 83549-8$.

Pakkanen, R., and J. Aalto. 1997. Growth factors and antimicrobial factors of bovine colostrum. Int. Dairy J. 7:285-297. https://doi .org/10.1016/S0958-6946(97)00022-8.

Parrish, D. B., G. H. Wise, and J. S. Hughes. 1949. Properties of the colostrum of the dairy cow. IV. Effect of form of vitamin A and of tocopherol supplements on concentrations of vitamin A and carotenoids. J. Dairy Sci. 32:458-464. https://doi.org/10.3168/jds .S0022-0302(49)92065-2.

Parrish, D. B., G. H. Wise, J. S. Hughes, and F. W. Atkeson. 1948. Properties of the colostrum of the dairy cow. II. Effect of prepartal rations upon the nitrogenous constituents. J. Dairy Sci. 31:889895. https://doi.org/10.3168/jds.S0022-0302(48)92273-5.

Patt, J. A. 1977. Factors affecting the duration of intestinal permeability to macromolecules in newborn animals. Biol. Rev. Camb. Philos. Soc. 52:411-429. https://doi.org/10.1111/j.1469-185X .1977.tb00855.x.

Pauletti, P., R. Machado Neto, I. U. Packer, R. D. D'Arce, and R. Bessi. 2003. Quality of colostral passive immunity and pattern of serum protein fluctuation in newborn calves. Sci. Agric. 60:453456. https://doi.org/10.1590/S0103-90162003000300006.

Peter, A. T. 2013. Bovine placenta: A review on morphology, components, and defects from terminology and clinical perspectives. Theriogenology 80:693-705. https://doi.org/10.1016/j.theriogenology 2013.06.004.

Pithua, P., S. M. Godden, S. J. Wells, and M. J. Oakes. 2009. Efficacy of feeding plasma-derived commercial colostrum replacer for the prevention of transmission of Mycobacterium avium subsp paratuberculosis in Holstein calves. J. Am. Vet. Med. Assoc. 234:11671176. https://doi.org/10.2460/javma.234.9.1167.

Priestley, D., J. H. Bittar, L. Ibarbia, C. A. Risco, and K. N. Galvão. 2013. Effect of feeding maternal colostrum or plasma-derived or colostrum-derived colostrum replacer on passive transfer of immunity, health, and performance of preweaning heifer calves. J. Dairy Sci. 96:3247-3256. https://doi.org/10.3168/jds.2012-6339. 
Pyo, J., K. Hare, S. Pletts, Y. Inabu, D. Haines, T. Sugino, L. L. Guan, and M. Steele. 2020. Feeding colostrum or a 1:1 colostrum: milk mixture for 3 days postnatal increases small intestinal development and minimally influences plasma glucagon-like peptide-2 and serum insulin-like growth factor-1 concentrations in Holstein bull calves. J. Dairy Sci. 103:4236-4251. https://doi.org/10.3168/ jds.2019-17219.

Quigley, J. 2004. The role of oral immunoglobulins in systemic and intestinal immunity of neonatal calves. Diamond V Mills.

Quigley, J. D., L. Deikun, T. M. Hill, F. X. Suarez-Mena, T. S. Dennis, and W. Hu. 2019. Effects of colostrum and milk replacer feed-ing rates on intake, growth, and digestibility in calves. J. Dairy Sci. 102:11016-11025. https://doi.org/10.3168/jds.2019-16682.

Quigley, J. D. Iii., and J. J. Drewry. 1998. Nutrient and immunity transfer from cow to calf pre- and postcalving. J. Dairy Sci. 81:2779-2790. https://doi.org/10.3168/jds.S0022-0302(98)75836 $-9$.

Quigley, J. D. III, J. J. Drewry, and K. R. Martin. 1998. Estimation of plasma volume in Holstein and Jersey calves. J. Dairy Sci. 81:1308-1312. https://doi.org/10.3168/jds.S0022-0302(98)75693 -0 .

Quigley, J. D., T. M. Hill, L. L. Deikun, and R. L. Schlotterbeck. 2017. Effects of amount of colostrum replacer, amount of milk replacer, and housing cleanliness on health, growth and intake of Holstein calves to 8 weeks of age. J. Dairy Sci. 100:9177-9185. https://doi .org/10.3168/jds.2017-12784.

Quigley, J. D. III, C. J. Kost, and T. M. Wolfe. 2002. Absorption of protein and IgG in calves fed a colostrum supplement or replacer. J. Dairy Sci. 85:1243-1248. https://doi.org/10.3168/jds.S0022 -0302(02)74188-X.

Quigley, J. D. III, K. R. Martin, and H. H. Dowlen. 1995a. Concentrations of trypsin inhibitor and immunoglobulins in colostrum of Jersey cows. J. Dairy Sci. 78:1573-1577. https://doi.org/10.3168/ jds.S0022-0302(95)76780-7

Quigley, J. D. III, K. R. Martin, H. H. Dowlen, and K. C. Lamar. 1995b. Addition of soybean trypsin inhibitor to bovine colostrum: Effects on serum immunoglobulin concentrations in Jersey calves. J. Dairy Sci. 78:886-892. https://doi.org/10.3168/jds.S0022 -0302(95)76702-9.

Quigley, J. D., R. E. Strohbehn, C. J. Kost, and M. M. O’Brien. 2001. Formulation of colostrum supplements, colostrum replacers and acquisition of passive immunity in neonatal calves. J. Dairy Sci. 84:2059-2065. https://doi.org/10.3168/jds.S0022-0302(01)74650 -4 .

Răducan, G. G., S. Acatincăi, L. Toma Cziszter, I. Tripon, and S. Erina. 2013. The dynamics of immunoglobulin IgG, IgA and IgI type concentration in milk colostrum. Lucr. Stiint. Zooteh. Biotehnol. 46:309.

Renaud, D. L., T. F. Duffield, S. J. LeBlanc, D. B. Haley, and D. F. Kelton. 2018. Clinical and metabolic indicators associated with early mortality at a milk-fed veal facility: A prospective case control study. J. Dairy Sci. 101:2669-2678. https://doi.org/10.3168/ jds.2017-14042.

Ribadeau-Dumas, B. 1983. Human milk. Endeavour 7:80-87.

Rochow, N., G. Fusch, A. Choi, L. Chessell, L. A. Elliott, K. McDonald, E. Kuiper, M. Purcha, S. Turner, E. Chan, M. Y. Xia, and C. Fusch. 2013. Target fortification of breast milk with fat, protein, and carbohydrates for preterm infants. J. Pediatr. 163:1001-1007. https://doi.org/10.1016/j.jpeds.2013.04.052.

Roy, J. 1972. Decision-making and calf health. J. R. Agric. Soc. Engl. 132:81.

Roy, J. H. B. 1980. Factors affecting susceptibility of calves to disease. J. Dairy Sci. 63:650-664. https://doi.org/10.3168/jds.S0022 -0302(80)82987-0.

Saldana, D. J., S. L. Gelsinger, C. M. Jones, and A. J. Heinrichs. 2019. Effect of different heating times of high-, medium-, and low-quality colostrum on immunoglobulin $\mathrm{G}$ absorption in dairy calves. J. Dairy Sci. 102:2068-2074. https://doi.org/10.3168/jds.2018-15542.

Sánchez, L., P. Aranda, M. D. Perez, and M. Calvo. 1988. Concentrations of lactoferrin and transferrin throughout lactation in cow's colostrum and milk. Biol. Chem. Hoppe. Seyler. 369:1005-1008.
Sandholm, M., and T. Honkanen-Buzalski. 1979. Colostral trypsin-inhibitor capacity in different spe- cies. Acta Vet. Scand. 20:469-476. https://doi.org/10.1186/BF03546574.

Sasaki, M., C. L. Davis, and B. L. Larson. 1976. Production and turnover of IgG1 and IgG2 immunoglobulins in the bovine around parturition. J. Dairy Sci. 59:2046-2055. https://doi.org/10.3168/jds .S0022-0302(76)84486-4.

Sasaki, M., C. L. Davis, and B. L. Larson. 1977. Immunoglobulin IgG1 metabolism in newborn calves. J. Dairy Sci. 60:623-626. https:// doi.org/10.3168/jds.S0022-0302(77)83910-6.

Selman, I. E., A. D. McEwan, and E. W. Fisher. 1971. Studies on dairy calves allowed to suckle their dams at fixed times postpartum. Res. Vet. Sci. 12:1-6. https://doi.org/10.1016/S0034-5288(18)34230-9.

Shivley, C. B., J. E. Lombard, N. J. Urie, D. M. Haines, R. Sargent, C. A. Kopral, T. J. Earleywine, J. D. Olson, and F. B. Garry. 2018. Preweaned heifer management on US dairy operations: Part II. Factors associated with colostrum quality and passive transfer status of dairy heifer calves. J. Dairy Sci. 101:9185-9198. https:// doi.org/10.3168/jds.2017-14008.

Silverstein, A. M. 1996. Paul Ehrlich: The founding of pediatric immunology. Cell. Immunol. 174:1-6. https://doi.org/10.1006/cimm .1996 .0286 .

Smeaton, T. C., and M. W. Simpson-Morgan. 1985. Epithelial cell renewal and antibody transfer in the intestine of the foetal and neonatal lamb. Aust. J. Exp. Biol. Med. Sci. 63:41-51. https://doi .org/10.1038/icb.1985.5.

Staley, T. E., L. D. Corley, L. J. Bush, and E. Wynn Jones. 1972. The ultrastructure of neonatal calf intestine and absorption of heterologous proteins. Anat. Rec. 172:559-579. https://doi.org/10.1002/ar .1091720310 .

Stelwagen, K., E. Carpenter, B. Haigh, A. Hodgkinson, and T. T. Wheeler. 2009. Immune components of bovine colostrum and milk. J. Anim. Sci. 87(suppl_13):3-9. https://doi.org/10.2527/jas.2008 $-1377$.

Stewart, S., S. Godden, R. Bey, P. Rapnicki, J. Fetrow, R. Farnsworth, M. Scanlon, Y. Arnold, L. Clow, K. Mueller, and C. Ferrouillet. 2005. Preventing bacterial contamination and proliferation during the harvest, storage, and feeding of fresh bovine colostrum. J. Dairy Sci. 88:2571-2578. https://doi.org/10.3168/jds.S0022 -0302(05)72933-7.

Stott, G. H., and A. Fellah. 1983. Colostral immunoglobulin absorption linearly related to concentration for calves. J. Dairy Sci. 66:13191328. https://doi.org/10.3168/jds.S0022-0302(83)81941-9.

Stott, G. H., W. A. Fleenor, and W. C. Kleese. 1981. Colostral immunoglobulin concentration in two fractions of first milking postpartum and five additional milkings. J. Dairy Sci. 64:459-465. https:/ /doi.org/10.3168/jds.S0022-0302(81)82594-5.

Stott, G. H., D. B. Marx, B. E. Menefee, and G. T. Nightengale. 1979a. Colostral immunoglobulin transfer in calves. IV. Effect of suckling. J. Dairy Sci. 62:1908-1913. https://doi.org/10.3168/jds S0022-0302(79)83522-5.

Stott, G. H., D. B. Marx, B. E. Menefee, and G. T. Nightengale. 1979b. Colostral immunoglobulin transfer in calves I. Period of absorption. J. Dairy Sci. 62:1632-1638. https://doi.org/10.3168/ jds.S0022-0302(79)83472-4.

Streeter, R. N., G. F. Hoffsis, S. Bech-Nielsen, W. P. Shulaw, and D. M. Rings. 1995. Isolation of Mycobacterium paratuberculosis from colostrum and milk of subclinically infected cows. Am. J. Vet. Res. $56: 1322-1324$

Swan, H., S. Godden, R. Bey, S. Wells, J. Fetrow, and H. ChesterJones. 2007. Passive transfer of immunoglobulin g and preweaning health in Holstein calves fed a commercial colostrum replacer. J. Dairy Sci. 90:3857-3866. https://doi.org/10.3168/jds.2007-0152.

Tacoma, R., S. L. Gelsinger, Y. W. Lam, R. A. Scuderi, D. B. Ebenstein, A. J. Heinrichs, and S. L. Greenwood. 2017. Exploration of the bovine colostrum proteome and effects of heat treatment time on colostrum protein profile. J. Dairy Sci. 100:9392-9401. https:// doi.org/10.3168/jds.2017-13211.

Thornhill, J. B., G. L. Krebs, and C. E. Petzel. 2015. Evaluation of the Brix refractometer as an on-farm tool for the detection of passive 
transfer of immunity in dairy calves. Aust. Vet. J. 93:26-30. https: //doi.org/10.1111/avj.12287.

Todd, C. G., M. McGee, K. Tiernan, P. Crosson, E. O'Riordan, J. McClure, I. Lorenz, and B. Earley. 2018. An observational study on passive immunity in Irish suckler beef and dairy calves: Tests for failure of passive transfer of immunity and associations with health and performance. Prev. Vet. Med. 159:182-195. https://doi.org/10 $.1016 / \mathrm{j}$.prevetmed.2018.07.014.

Tsioulpas, A., A. S. Grandison, and M. J. Lewis. 2007. Changes in physical properties of bovine milk from the colostrum period to early lactation. J. Dairy Sci. 90:5012-5017. https://doi.org/10 .3168/jds.2007-0192.

Tyler, J. W., D. D. Hancock, S. M. Parish, D. E. Rea, T. E. Besser, S. G. Sanders, and L. K. Wilson. 1996. Evaluation of 3 assays for failure of passive transfer in calves. J. Vet. Intern. Med. 10:304-307. https://doi.org/10.1111/j.1939-1676.1996.tb02067.x.

Urie, N. J., J. E. Lombard, C. B. Shivley, A. E. Adams, C. A. Kopral, and M. Santin. 2018a. Preweaned heifer management on US dairy operations: Part III. Factors associated with Cryptosporidium and Giardia in preweaned dairy heifer calves. J. Dairy Sci. 101:91999213. https://doi.org/10.3168/jds.2017-14060.

Urie, N. J., J. E. Lombard, C. B. Shivley, C. A. Kopral, A. E. Adams, T. J. Earleywine, J. D. Olson, and F. B. Garry. 2018b. Preweaned heifer management on US dairy operations: Part V. Factors as sociated with morbidity and mortality in preweaned dairy heifer calves. J. Dairy Sci. 101:9229-9244. https://doi.org/10.3168/jds .2017-14019.

USDA. 2010. Heifer calf health and management practices on U.S. Dairy Operations, 2007. USDA-APHIS-VS-CEAH-NAHMS. Accessed Jun. 15, 2016. https://www.aphis.usda.gov/animal_health/ nahms/dairy/downloads/dairy07/Dairy07_ir_CalfHealth.pdf.
Waldner, C. L., and L. B. Rosengren. 2009. Factors associated with serum immunoglobulin levels in beef calves from Alberta and Saskatchewan and association between passive transfer and health outcomes. Can. Vet. J. 50:275-281.

Weaver, D. M., J. W. Tyler, D. C. VanMetre, D. E. Hostetler, and G. M. Barrington. 2000. Passive transfer of colostral immunoglobulins in calves. J. Vet. Intern. Med. 14:569-577. https://doi.org/10 .1111/j.1939-1676.2000.tb02278.x.

Weiss, W. P., D. A. Todhunter, J. S. Hogan, and K. L. Smith. 1990 Effect of duration of supplementation of selenium and vitamin $\mathrm{E}$ on periparturient dairy cows. J. Dairy Sci. 73:3187-3194. https:// doi.org/10.3168/jds.S0022-0302(90)79009-1.

Weaver, D. M., J. W. Tyler, D. C. VanMetre, D. E. Hostetler, and G. M. Barrington. 2000. Passive transfer of colostral immunoglobulins in calves. J. Vet. Intern. Med. 14:569-577. https://doi.org/10 .1111/j.1939-1676.2000.tb02278.x.

Wilm, J., J. H. C. Costa, H. W. Neave, D. M. Weary, and M. A. G. von Keyserlingk. 2018. Technical note: Serum total protein and immunoglobulin $\mathrm{G}$ concentrations in neonatal dairy calves over the first 10 days of age. J. Dairy Sci. 101:6430-6436. https://doi.org/ $10.3168 /$ jds.2017-13553.

Yvon, M., J. P. Pelissier, P. Guilloteau, and R. Toullec. 1984. In vivo milk digestion in the calf abomasum. I. Whole-casein digestion. Reprod. Nutr. Dev. 24(5A):587-595. https://doi.org/10.1051/rnd: 19840507.

Zanker, I. A., H. M. Hammon, and J. W. Blum. 2000. Beta-carotene, retinol and alpha-tocopherol status in calves fed the first colostrum at $0-2,6-7,12-13$ or $24-25$ hours after birth. Int. J. Vitam. Nutr. Res. 70:305-310. https://doi.org/10.1024/0300-9831.70.6.305. 